\title{
Precise age and petrology of Silurian-Devonian plutons in the Benjamin River - Charlo area, northern New Brunswick
}

\author{
Jean-Luc Pilote ${ }^{1 *}$, Sandra M. BarR ${ }^{1}$, Reginald A. Wilson ${ }^{2}$, Sean McClenaghan ${ }^{2}$, \\ Sandra Kamo 3 , Vicki J. McNicoll 4 , ANd Mary Lou Bevier ${ }^{5}$ \\ 1. Department of Earth and Environmental Science, Acadia University, Wolfville, Nova Scotia, B4P 2R6 Canada \\ 2. Geological Surveys Branch, New Brunswick Department of Natural Resources, Bathurst, New Brunswick, \\ E2A 3Z1 Canada \\ 3. Jack Satterly Geochronology Laboratory, Department of Geology, University of Toronto, Toronto, Ontario, \\ M5S 3B1 Canada \\ 4. Geological Survey of Canada, Ottawa, Ontario, K1A 0E4 Canada \\ 5. Department of Earth and Ocean Sciences, The University of British Columbia, Vancouver, British Columbia, \\ V6T 1Z4 Canada
}

*Corresponding author: $<096594 \mathrm{p} @$ acadiau.ca $>$

Date received: 19 April 2012 Date accepted: 02 July 2012

\begin{abstract}
The Late Silurian Landry Brook and Dickie Brook plutons and Charlo plutonic suite underlie a combined area of approximately $80 \mathrm{~km}^{2}$ in the northeastern part of the Ganderian Tobique-Chaleur tectonostratigraphic belt in northern New Brunswick. The Landry Brook pluton is divided into three units: gabbro to quartz diorite, quartz monzodiorite to monzogranite, and monzogranite. A sample from the quartz monzodiorite unit yielded a U-Pb (zircon) crystallization age of $419.63 \pm 0.23 \mathrm{Ma}$. A granodioritic stock located near the Landry Brook pluton has yielded an age of $400.7 \pm 0.4 \mathrm{Ma}$, indicating that it is a younger unrelated body, herein referred to as the Blue Mountain Granodiorite (new name). The Dickie Brook pluton also consists of three units: leucogabbro to quartz gabbro, diorite to quartz diorite and quartz monzodiorite to monzogranite. Two samples from the monzogranite unit yielded U-Pb (zircon) crystallization ages of $418 \pm 1 \mathrm{Ma}$ and $418.1 \pm 1.3 \mathrm{Ma}$. The Charlo plutonic suite is a group of small plutons and dykes, located west of the Dickie Brook and Landry Brook plutons and consists mainly of diabase, quartz monzonite to monzogranite, rhyolite porphyry, and dacite porphyry. Chemical trends indicate that the quartz monzodiorite to monzogranite unit of the Landry Brook pluton, all of the units of the Dickie Brook pluton, and the quartz monzodiorite to monzogranite unit of the Charlo plutonic suite, as well as the volcanic host rocks of the Bryant Point and Benjamin formations, are co-magmatic. They formed following slab break-off and extension in the waning stages of the Salinic orogeny, which resulted from the collision of Ganderia and Laurentia. In contrast, the dacite porphyry of the Charlo plutonic suite may be cogenetic with the younger Blue Mountain Granodiorite and related to the collision of Avalonia with Laurentia.
\end{abstract}

\section{RÉSUMÉ}

Les plutons des ruisseaux Landry et Dickie et le cortège plutonique de Charlo, du Silurien tardif, recouvrent une superficie totale denviron $80 \mathrm{~km}^{2}$ dans la partie nord-est du domaine tectonostratigraphique gandérien Tobique-Chaleur, dans le nord du Nouveau-Brunswick. Le pluton du ruisseau Landry se compose de trois unités : du gabbro à de la diorite quartzique, de la monzodiorite quartzique au monzogranite, et du monzogranite. Un échantillon de l'unité de monzodiorite quartzique a produit un âge de cristallisation de 419,63 $\pm 0,23$ Ma par la méthode de datation $\mathrm{U}-\mathrm{Pb}$ (sur zircon). Un bloc de granodiorite à proximité du pluton du ruisseau Landry a produit un âge de 400,7 $\pm 0,4 \mathrm{Ma}$, ce qui indiquerait qu'il s'agit d'un corps de formation plus récente et non relié, désigné ici comme la granodiorite de Blue Mountain (nouveau nom). Le pluton du ruisseau Dickie comprend lui aussi trois unités : du leucogabbro à du gabbro quartzique, de la diorite à de la diorite quartzique, et de la monzodiorite 
quartzique à du monzogranite. Deux échantillons de monzogranite ont produit des âges de cristallisation de $418 \pm$ $1 \mathrm{Ma}$ et de 418,1 \pm 1,3 Ma, selon la méthode de datation $\mathrm{U}-\mathrm{Pb}$ (sur zircon). Le cortège plutonique de Charlo est un groupe de plutons et de dykes de petite taille, situé à l'ouest des plutons du ruisseau Dickie et du ruisseau Landry, et il se compose de diabase, de monzonite quartzique à du monzogranite, de porphyre rhyolitique, et de porphyre dacitique. Les tendances chimiques indiquent une nature comagmatique en ce qui concernel'unité de monzodiorite quartzique au monzogranite du pluton du ruisseau Landry, la totalité des unités du pluton du ruisseau Dickie, ainsi que l'unité monzodiorite quartzique au monzogranite du cortège plutonique de Charlo, tout comme pour les roches volcaniques encaissantes des Formations Bryant Point et Benjamin. Ces structures sont apparues après la rupture de la plaque et son extension aux derniers stades de l'orogenèse salinique, provoquée par la collision des anciens continents de Gandérie et de Laurentie. Par contraste, le porphyre dacitique du cortège plutonique de Charlo peut sêtre formé sous les mêmes conditions que celles ayant présidé à l'apparition de la granodiorite plus récente de Blue Mountain et être associé à la collision des anciens continents d’Avalon et de Laurentie.

[Traduit par la redaction]

\section{INTRODUCTION}

Central and northern New Brunswick contains voluminous Silurian-Devonian plutonic and volcanic rocks displaying a continuous spectrum from mafic to felsic compositions (e.g., Whalen 1993; Wilson et al. 2008). The focus of this study, the Landry Brook and Dickie Brook plutons and a group of smaller plutons, dykes, and sills referred to here as the Charlo plutonic suite, are part of this widespread mid-Paleozoic magmatism, but are spatially isolated from other plutonic manifestations of the magmatic event. These plutonic rocks range in composition from gabbro to monzogranite and, collectively, cover an area of approximately $80 \mathrm{~km}^{2}$ (Fig. 1). Although generally assumed to be consanguineous and Devonian, the ages of these plutons were in fact uncertain prior to the present study. Stewart (1979) reported an imprecise age of $370 \pm$ $30 \mathrm{Ma}$ (whole-rock Rb-Sr) for the Landry Brook pluton, and later an unpublished U-Pb (zircon) age of $400 \pm 1 \mathrm{Ma}$ was obtained (V. McNicoll; reported in Wilson et al. 2004) from a separate granodiorite stock southwest of the Landry Brook pluton; however, its relationship to that pluton was uncertain. Data from this latter stock are included in this study, and geochemical comparisons are made with adjacent intrusive rocks. The Landry Brook and Dickie Brook plutons and Charlo plutonic suite are excellent targets for petrological and geochronological study, to add new information to models for northern Appalachian magmatic and tectonic evolution.

The purpose of this paper is to describe the field relationships and petrology of these plutons, to present new and older (but previously unpublished) U-Pb (zircon) data that closely constrain the age of the Landry Brook and Dickie Brook plutons and spatially associated stocks, and to interpret their petrogenesis and tectonic setting at the time of emplacement. Based on geochemical and age similarities, we further suggest that the host volcanic rocks of the Benjamin and Bryant Point formations are likely genetically related to (i.e., the extrusive equivalents of) the plutons.

\section{GEOLOGICAL SETTING}

The Landry Brook pluton, Dickie Brook pluton, and Charlo plutonic suite intruded rocks that are part of the mid-Paleozoic Appalachian realm of Ganderia and its cover sequence (Fig. 2). At regional scale, Ordovician rocks in this area are part of the Popelogan-Victoria arc subzone (Hibbard et al. 2006; van Staal 2007; van Staal et al. 2009) and are covered by the Silurian-Devonian Chaleur Bay Synclinorium (part of the Gaspé Belt; Wilson et al. 2004), which includes rocks of the Quinn Point, Dickie Cove, Petit Rocher, and Dalhousie groups (Wilson and Kamo 2012). The Silurian rocks in the study area include the Upsalquitch Formation (Quinn Point Group), and the Bryant Point, New Mills, and Benjamin formations (Dickie Cove Group; Fig. 1).

The Llandoverian Upsalquitch Formation (Fig. 1) is generally composed of calcareous, micaceous siltstone and fine-grained sandstone (McCutcheon and Bevier 1990). It is disconformably overlain by the Ludlovian Bryant Point Formation, which is composed of greyish-green to maroon, locally highly porphyritic and amygdaloidal basaltic flows with plagioclase phenocrysts up to $3 \mathrm{~cm}$ in length. It is estimated to be about $650 \mathrm{~m}$ thick at the type locality (Walker and McCutcheon 1995). The New Mills Formation overlies the Bryant Point Formation, and is composed of red pebblecobble conglomerate, sandstone and siltstone, and minor mafic and felsic volcanic flows. Cobbles and pebbles in the conglomerate are composed of mafic and felsic volcanic rocks, derived from underlying and coeval formations. The large size of many of the boulders, their lack of orientation, and poor stratification suggest deposition as subaerial debris 


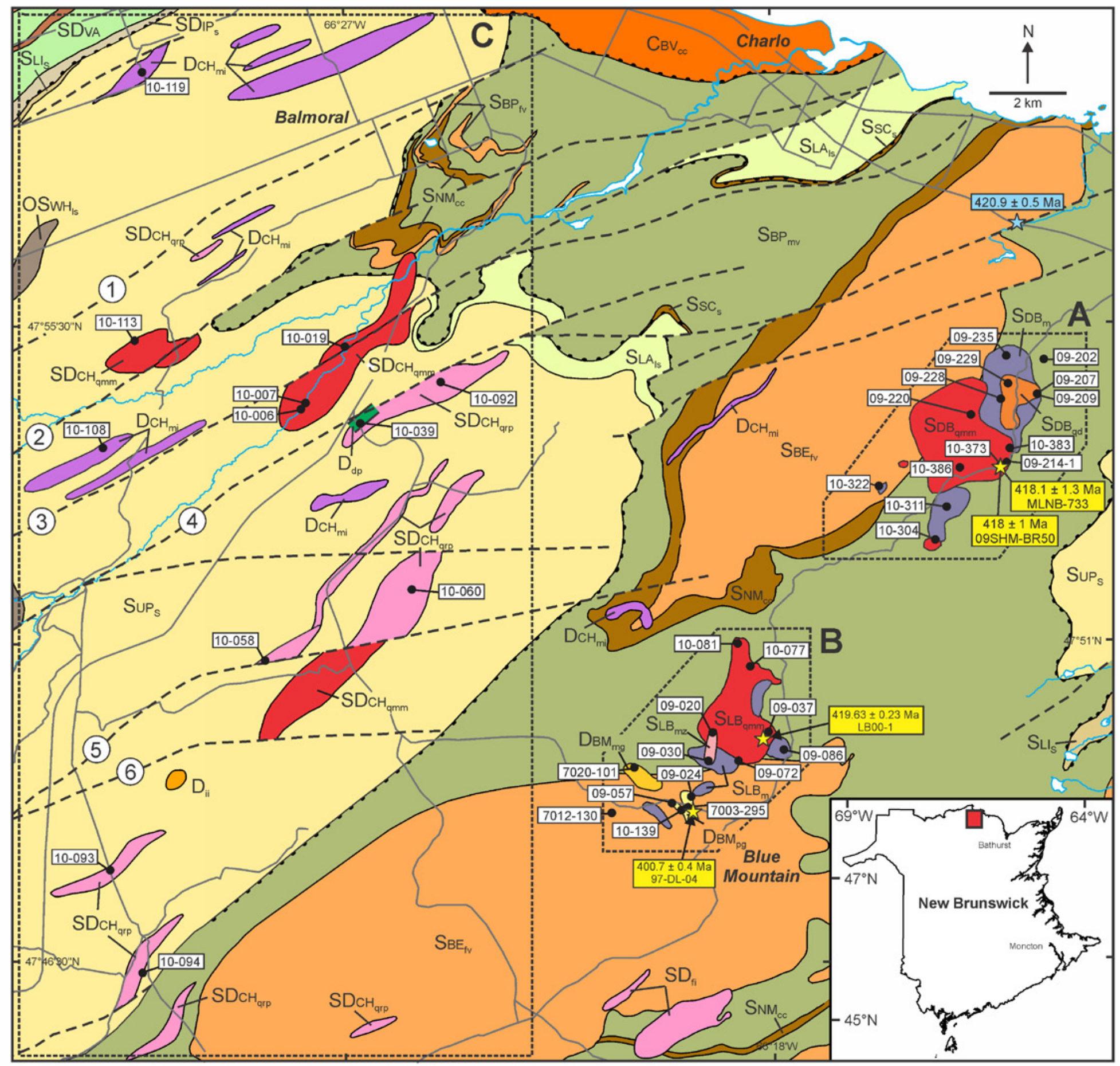

FAULTS

1. Rocky Gulch

2. Chouinard Brook

3. White Meadows

4. Indian Lake

5. South Charlo River

6. Popelogan Lake
Geological contact

Angular unconformity or disconformity

Fault

Fig. 1a. Simplified geological map of the study based on Irrinki (1990), Langton (2000, 2001, 2004), Wilson (2000, 2003), and Wilson and Kamo (2012). Areas A, B, and C show the distribution of the Dickie Lake pluton, Landry Brook pluton and Blue Mountain Granodiorite, and the Charlo plutonic suite, respectively. Map legend is in Figure $1 \mathrm{~b}$. 


\section{LEGEND}
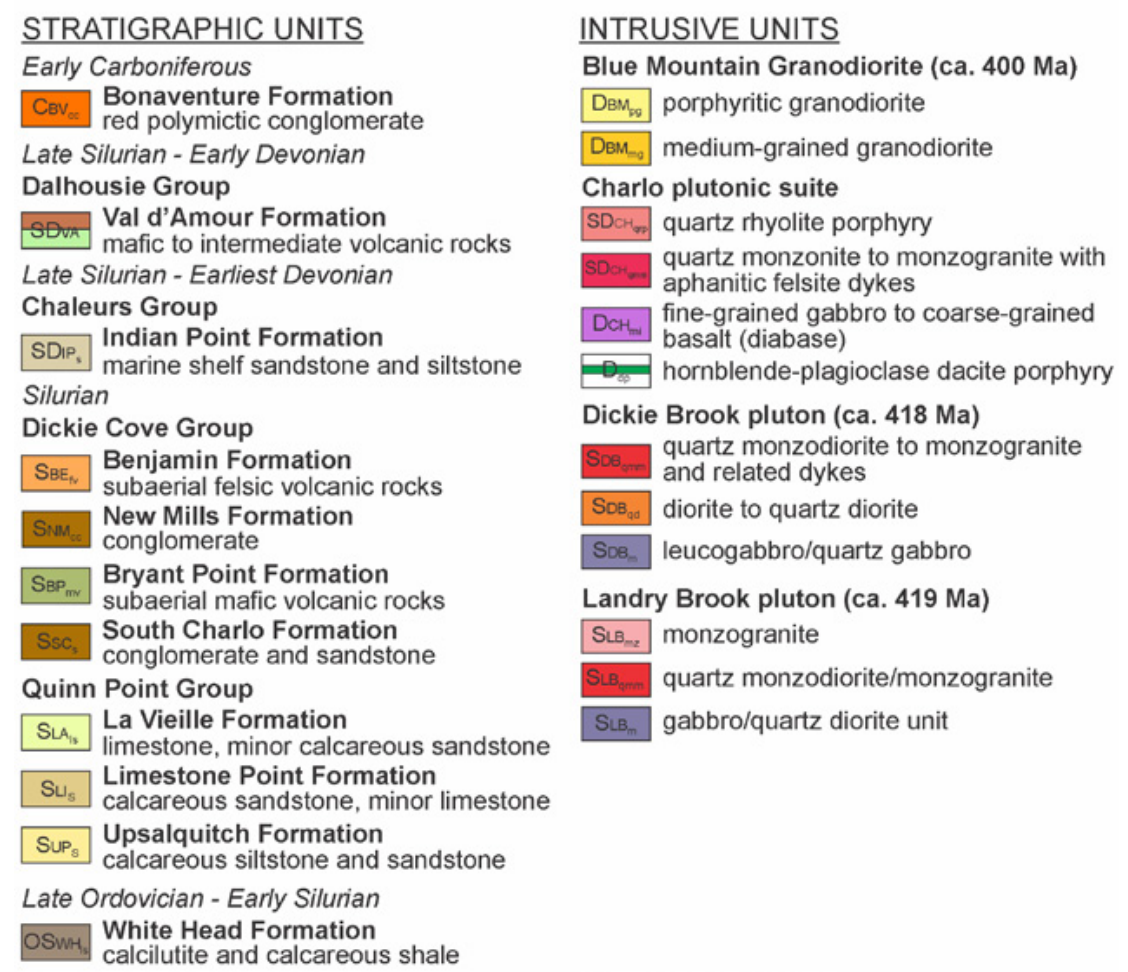

Fig. 1b. Legend for Figure 1a (after Wilson and Kamo 2012).

flows (Greiner 1970; Irrinki 1990; Walker et al. 1993; Walker and McCutcheon 1995). The formation is approximately $120 \mathrm{~m}$ thick, and is overlain by and interfingers with felsic volcanic rocks of the Benjamin Formation. The latter formation is composed of pale red, flow-banded, sparsely porphyritic rhyolite, and also includes feldspar crystal tuff, pumaceous lapilli tuff and, at the top of the formation, basalt (McCutcheon and Bevier 1990). The Benjamin Formation is late Ludfordian to early Pridolian in age, and yielded $\mathrm{U}-\mathrm{Pb}$ (zircon) ages of $420.8 \pm 0.4 \mathrm{Ma}$ (Wilson and Kamo 2008) and $419.7 \pm 7 \mathrm{Ma}$ (Wilson and Kamo 2012) at different localities. The former dated sample was collected $3.5 \mathrm{~km}$ north of the northern tip of the Dickie Brook pluton (Fig. 1), and the latter $14 \mathrm{~km}$ south of the southern part of the Landry Brook pluton (not shown on Fig. 1).

\section{FIELD RELATIONS AND PETROGRAPHY}

\section{Terminology}

The Landry Brook pluton was previously termed the "Benjamin River intrusive complex" by Stewart (1979), and the Landry Brook, Dickie Brook and Charlo intrusions were later collectively referred to as the "Charlo stocks" (Fyffe et al. 1981). Whalen (1993) considered the Landry Brook and Dickie Brook plutons as two separate plutons forming the "Benjamin River complex". However, to avoid any terminology conflict with some of the host rocks (i.e., the Benjamin Formation), the names Landry Brook and Dickie Brook were introduced; both names derive from brooks that are tributaries of the Benjamin River, which transects both plutons. The formal names of these plutons in the New Brunswick bedrock lexicon are the Landry Brook Quartz Monzonite and Dickie Brook Quartz Monzonite; however, to avoid exclusivity in the various rock types forming them, they are referred herein simply as plutons. The term Charlo plutonic suite is used here only for small plutons, dykes, and sills that occur over a large area west of the Landry Brook and Dickie Brook plutons (Fig. 1). These small bodies were referred to as the "Charlo stocks" by Whalen (1993); the formal name in the New Brunswick bedrock lexicon is the Charlo Granite. As discussed later in the text, the name Blue Mountain Granodiorite is introduced for two granodioritic stocks south and southwest of the Landry Brook pluton. The name is derived from Blue Mountain, a topographic feature in the area (Fig. 1). However, gabbroic bodies in the same area are interpreted to be part of the Landry Brook pluton, based on petrological features described below. 


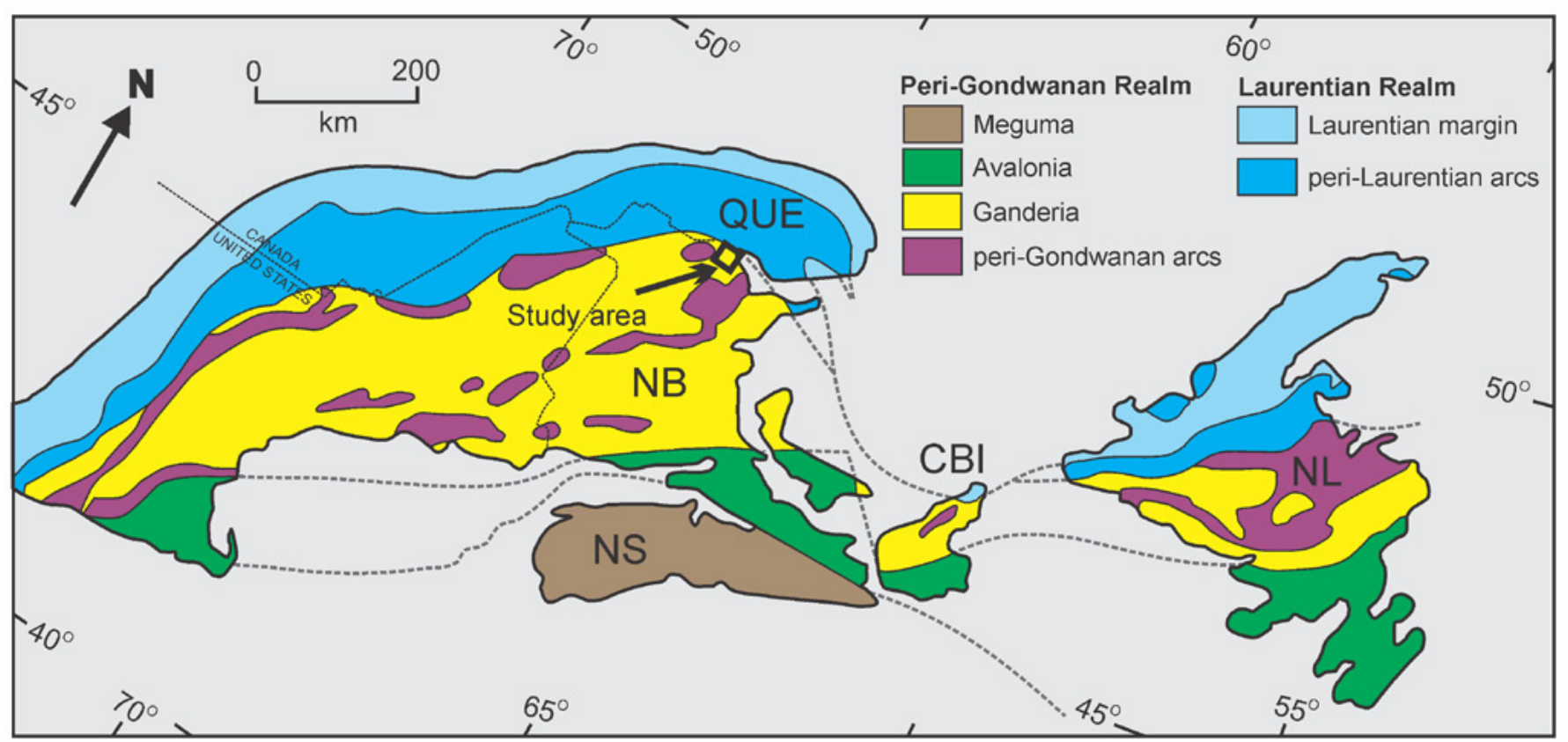

Fig. 2. Tectonostratigraphic divisions in the Canadian Appalachians modified after Hibbard et al. (2006) showing the location of the study area (box) in Ganderia in northern New Brunswick. Abbreviations: CBI, Cape Breton Island; NB, New Brunswick; NL, Newfoundland and Labrador; NS, Nova Scotia; QUE, Québec.

\section{Field Relationships}

\section{Landry Brook pluton and Blue Mountain Granodiorite}

The Landry Brook pluton consists of one main composite intrusion and a few small gabbroic bodies located southwest of the main intrusion (Fig. 1). The latter area is also the location of the Blue Mountain Granodiorite stocks, which were originally considered to be genetically related to the Landry Brook pluton, but are discussed separately here.

The most abundant rock type in the Landry Brook pluton is quartz monzodiorite to monzogranite, which makes up most of the pluton. Other lithotypes include gabbro/quartz diorite and late monzogranite. Throughout the area, exposure is poor; hence, cross-cutting and other contact relations are difficult to observe. In addition to field observations, 16 drill holes were re-logged in order to reassess the relationships with the smaller plutons to the southwest of the main body. Based on these observations and prior to geochronological work, the sequence of emplacement was inferred to be gabbro/quartz diorite, followed by mediumgrained granodiorite, porphyritic granodiorite and quartz monzodiorite to monzogranite (QMM), and lastly the monzogranite. All these plutonic rocks intruded mafic flows and felsic flows and pyroclastic rocks of the Bryant Point and Benjamin formations, respectively. The gabbro to diorite (or leucogabbro) occurs also as xenoliths in the QMM (Figs. 3a, b); the xenoliths are angular to irregular (e.g., ovoid) in shape and range widely in size ( $\mathrm{cm}$ to $\mathrm{m}$ scale). Contacts between the gabbro and the QMM are gradational to sharp and the late monzogranite clearly cross-cuts both the QMM and gabbro (Fig. 3b), as xenoliths are present in a monzogranite dyke in the northeastern part of the pluton.

Porphyritic granodiorite (Fig. 3c) and medium-grained granodiorite (Fig. 3d) of the Blue Mountain Granodiorite have clear intrusive relationships relative to both the early gabbro and the late monzogranite of the Landry Brook pluton. In both cases contacts are sharp and well defined; chilled margins and marginal alteration of feldspar grains were observed in places. The relationship of the Blue Mountain Granodiorite to the QMM of the Landry Brook pluton is uncertain, as no contacts were observed. Geochronological and geochemical analyses of the Blue Mountain Granodiorite (see below) demonstrate that it is unrelated to the Landry Brook pluton, and the product of a much younger magmatic event.

\section{Dickie Brook pluton}

Like the Landry Brook pluton, the Dickie Brook pluton and associated dykes intruded mafic flows and felsic flows and pyroclastic rocks of the Bryant Point and Benjamin formations, respectively. Most of the northeastern and southern parts of the Dickie Brook pluton consist of medium-grained gabbro to quartz gabbro and quartz diorite (Fig. 1). These areas are also cut by diabasic dykes trending northwest-southeast. The contact between the light-coloured quartz diorite and somewhat darker gabbro is subtle but visible in some places (Fig. 3e). The contact is typically sharp, 
suggesting that the gabbro had cooled prior to subsequent intrusion of the quartz diorite. Dykes of granodiorite composition (slightly higher in quartz and K-feldspar) cut the gabbro and quartz diorite and may be related to the quartz monzodiorite/monzogranite unit that forms more than half of the pluton (Fig. 1). Near the eastern margin, the contact between quartz diorite and gabbro is irregular (e.g., cuspatelobate margins) but towards the west, the contact is sharp and angular. Xenoliths of leucogabbro or quartz diorite were also observed in the quartz monzodiorite/monzogranite (Fig. 3f), indicating that the latter is the youngest unit in the pluton. Flow during emplacement/cooling is suggested by the presence of schlieren or flow layering in the leucogabbro. Hence, small aphanitic diabasic dykes appear to have been boudinaged, possibly by host magma movement during their emplacement. Close to its contact with the host rocks of the Bryant Point and Benjamin formations, the quartz monzodiorite/monzogranite contains centimetre- to metrescale xenoliths of basalt (probably from the Bryant Point Formation). A melanocratic monzogranite dyke in the Bryant Point Formation north of the pluton is interpreted to be related to the quartz monzodiorite/monzogranite unit based on texture and mineralogy. Diabasic and aphanitic felsic dykes, probably late phases of the pluton, cut the quartz monzodiorite/monzogranite, and are especially visible along the South Branch Benjamin River.

\section{Charlo plutonic suite}

The plutons, dykes, and sills of the Charlo plutonic suite consist of varied intermediate to felsic rock including quartz monzonite to monzogranite, quartz-plagioclase rhyolite porphyry, hornblende dacite porphyry, and felsite. They intruded calcareous sedimentary rocks of the Upsalquitch Formation (Fig. 1) and are typically oriented southwestnortheast, parallel to regional strike of bedding and cleavage. Diabase dykes, also oriented southwest-northeast, are abundant in the area, and are assumed to be mainly younger than the felsic rocks, based on cross-cutting relationships observed in several places. Some of the diabase bodies are concordant with bedding and hence sill-like; vugs at the tops of these sills indicate way-up.

Small areas of skarn were observed in the calcareous rocks throughout the area adjacent to the intrusions. A drilling project in 1996-97 by Noranda Inc. evaluated the potential for skarn mineralization; however, no further work has been carried out since then. The drill cores, stored at Madran, New Brunswick, were examined and the lithotypes intersected in drill core correspond to those seen in surface outcrops.

The quartz monzonite to monzogranite occurs in three plutonic bodies; it is cut by later felsite dykes (Fig. 3g) and has sharp contacts with the host rocks. It is possible that the felsite and quartz-plagioclase rhyolite porphyry dykes are somewhat younger than the quartz monzonite, assuming they are all comagmatic. This hypothesis is supported by cross-cutting relationships with the quartz monzonite, but also by their similarity to the late felsite dykes in the Landry Brook and Dickie Brook plutons. Alteration in the rhyolite porphyry is pervasive, indicated by abundant chlorite and calcite veins. The abundance of aligned miarolitic cavities parallel to primary flow fabric suggests that these bodies were emplaced at high levels. No cross-cutting relationships were observed between the hornblende dacite porphyry (Fig. 3h) and the other units.

\section{Petrography}

\section{Blue Mountain Granodiorite}

Porphyritic (hiatal to seriate) granodiorite has plagioclase $\left(\sim \mathrm{An}_{25}\right)$ phenocrysts varying from 3 to $5 \mathrm{~mm}$ in size, with an altered fine-grained groundmass composed of $\mathrm{K}$-feldspar and quartz (Fig. 4a). In contrast, the mediumgrained granodiorite consists of quartz, plagioclase $\left(\mathrm{An}_{36-}\right.$ ${ }_{41}$ ), biotite, and minor hornblende (Fig. $4 \mathrm{~b}$ ). It is also less altered than the porphyritic granodiorite. Hence they are texturally and mineralogically distinct, although both host disseminated sulphide minerals (e.g. pyrite, chalcopyrite). A summary of plutonic units and petrographic features are presented in Appendix 1.

\section{Landry Brook pluton}

The main body of the Landry Brook pluton varies from quartz monzodiorite to quartz monzonite and monzogranite, depending mainly on the relative abundance of K-feldspar. Colour varies from light grey to dark brick red with increasing degree of alteration. Most of these rocks are medium-grained and in some areas they are porphyritic with zoned plagioclase phenocrysts (Fig. 4c). They contain abundant xenoliths of gabbro/diorite and basalt, the latter likely from the host Bryant Point Formation. The youngest component of the pluton is fine- to mediumgrained monzogranite, which in places contains plagioclase phenocrysts in a fine-grained groundmass (Fig. 4d).

Gabbro is generally medium to dark grey and the grain size varies from fine to medium; quartz diorite is texturally similar to the gabbro but lighter in colour. Both the gabbro and quartz diorite consist of plagioclase $\left(\mathrm{An}_{44-63}\right)$, diopside and/or calcic hornblende, magnetite and minor quartz (less than 5\%). 

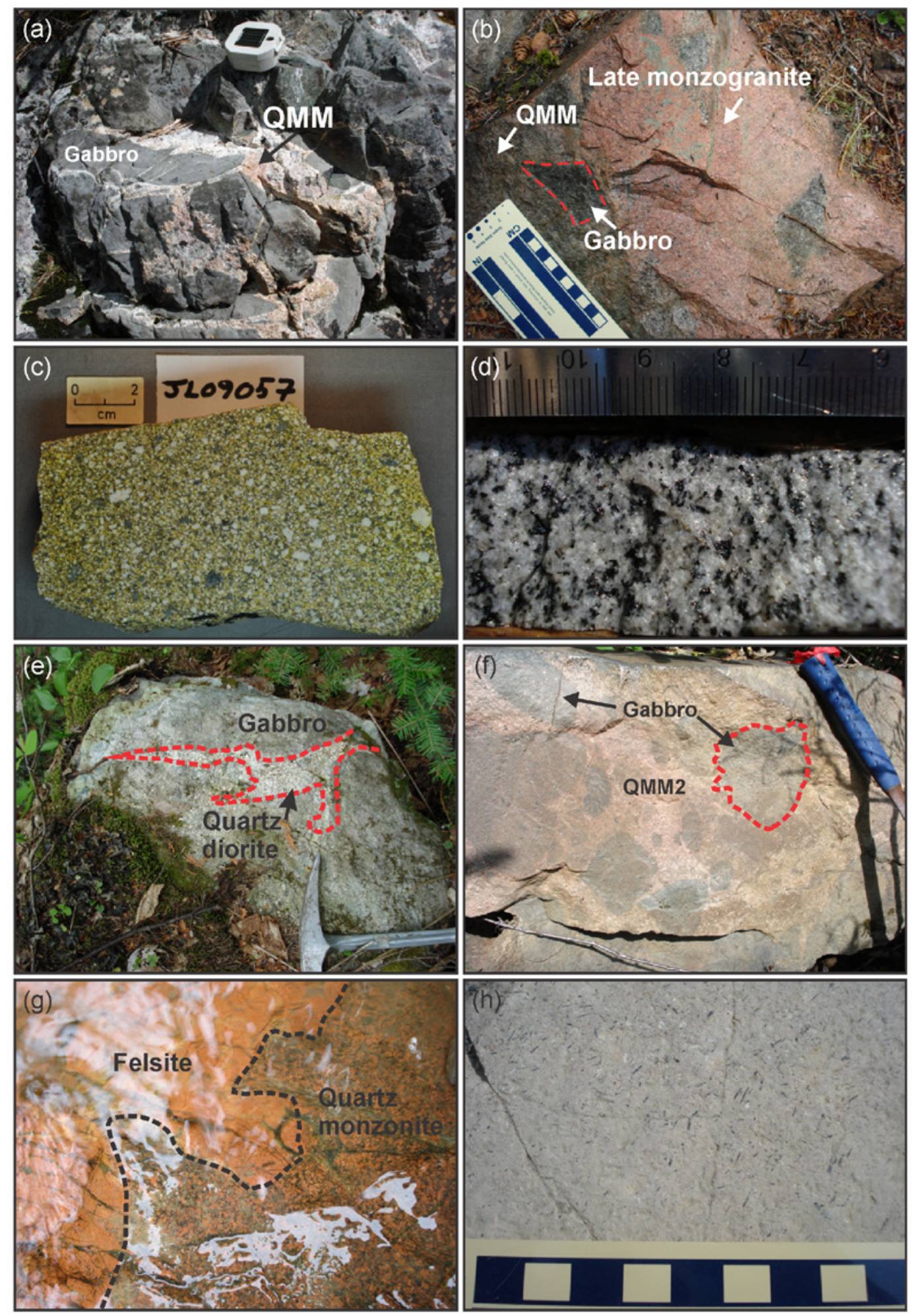

Fig. 3. Photographs of sample and outcrop features of Landry Brook and Dickie Brook plutons and Charlo plutonic suite. (a) Cross-cutting relationship between gabbro and quartz monzodiorite in the Landry Brook pluton. (b) Late monzogranite cutting quartz monzodiorite and gabbro in the Landry Brook pluton. (c) Slab of porphyritic granodiorite from the Blue Mountain Granodiorite, stained for K-feldspar (yellow). (d) Slab of medium-grained granodiorite (from DDH 7020-101') from the Blue Mountain Granodiorite. (e) Outcrop photograph showing quartz diorite intruded into leucogabbro in the Dickie Brook pluton. (f) Outcrop photograph showing xenoliths of gabbro in monzogranite of the Dickie Brook pluton. (g) Outcrop photograph of quartz monzonite intruded by felsite dyke in the Charlo plutonic suite. (h) Slab of sample JL10-039 from the hornblende dacite porphyry dyke in the Charlo plutonic suite with flow-oriented hornblende laths. 

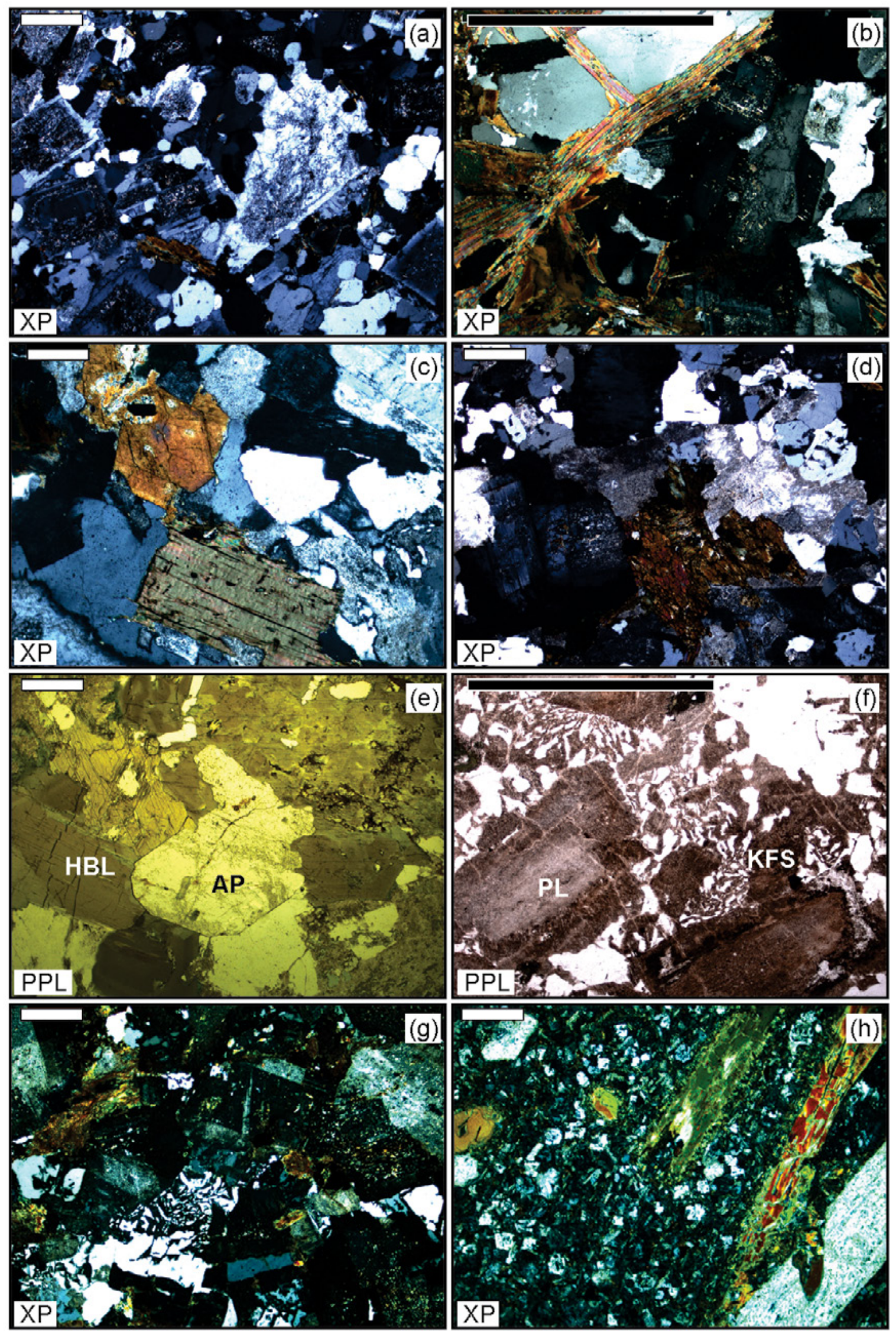
Fig. 4. Petrographic features of the Landry Brook and Dickie Brook plutons and Charlo plutonic suite. (a) Photomicrograph of porphyritic granodiorite from the Blue Mountain Granodiorite showing euhedral to subhedral zoned plagioclase with interstitial quartz, plagioclase and K-feldspar. (b) Photomicrograph of medium-grained granodiorite from the Blue Mountain Granodiorite showing hypidiomorphic equigranular texture with plagioclase, quartz, K-feldspar, and biotite. (c) Photomicrograph of medium-grained quartz monzonite from the Landry Brook pluton showing allotriomorphic inequigranular texture with zoned plagioclase surrounded by K-feldspar and interstitial quartz. Tabular dark pleochroic brown biotite coexists with subhedral green hornblende. (d) Photomicrograph of medium-grained monzogranite from the Landry Brook pluton showing subhedral plagioclase, interstitial K-feldspar and anhedral quartz with altered hornblende. (e) Photomicrograph of coarse-grained quartz diorite from the Dickie Brook pluton showing plagioclase, quartz with anhedral apatite and altered actinolite-hornblende. (f) Photomicrograph of medium-grained granophyric quartz monzogranite from the Dickie Brook pluton showing minor mafic minerals (less than 10\%). (g) Photomicrograph of medium-grained granophyric monzogranite from the Charlo plutonic suite showing highly sericitized plagioclase and K-feldspar with chloritized fine-grained biotite grains. (h) Photomicrograph of hornblende dacite porphyry from the Charlo plutonic suite showing twinned K-feldspar and skeletal hornblende laths with some completely mantled by K-feldspar. Abbreviation: XP, cross-polarized light; PPL, plane-polarized light; AP, apatite; HBL, hornblende; KFS, K-feldspar; PL, plagioclase. Scale bar is $1 \mathrm{~mm}$.

\section{Dickie Brook pluton}

Mafic rocks of the Dickie Brook pluton vary in composition, and include gabbro, leucogabbro to quartz gabbro, and diorite to quartz diorite. Gabbro and quartz gabbro contain a higher proportion of mafic minerals, mainly clinopyroxene, than the leucogabbro. The diorite/quartz diorite (Fig. 4e) is lighter in colour that the gabbroic rocks but with similar medium to coarse grain size. The quartz content is higher than in the gabbroic rocks and the main mafic mineral is hornblende rather than clinopyroxene.

Quartz monzodiorite/monzogranite (Fig. 4f) is typically light pink to dark red, medium-grained and equigranular, but in some places it is porphyritic with phenocrysts of plagioclase $\left(\sim \mathrm{An}_{45}\right)$. This unit is fairly homogeneous throughout in terms of texture and composition. Mafic minerals include biotite and hornblende, and titanite as a prominent accessory phase.

\section{Charlo plutonic suite}

The main rock types in the Charlo plutonic suite are diabase to gabbro, quartz monzonite to monzogranite, quartz rhyolite porphyry, and hornblende dacite porphyry. The gabbro and diabase occur both as small plutons and as dykes; they are dark grey, fine- to medium-grained, and contain augite-diopside, plagioclase, and magnetite. The quartz monzonite to monzogranite (Fig. $4 \mathrm{~g}$ ) is fineto medium-grained, and consists of zoned phenocrysts of plagioclase (ranging $\mathrm{An}_{17-57}$ from rim to core) in a finegrained groundmass consisting of granophyric quartz and $\mathrm{K}$-feldspar. It is similar in mineralogy and texture to the quartz monzodiorite/monzogranite units in the Landry Brook and Dickie Brook plutons, and is likely related to them (see Discussion). Miarolitic cavities are abundant, consistent with high-level emplacement. The quartz rhyolite porphyry occurs as dykes that vary from light grey to dark pink depending on the degree of alteration. Quartz phenocrysts are abundant, as are miarolitic cavities. At some locations, sulphide concentration is relatively high. Hornblende dacite porphyry (Fig. $4 \mathrm{~h}$ ) is medium grey, and has hornblende phenocrysts ranging from 3 to $5 \mathrm{~mm}$ in size in an aphanitic groundmass. The phenocrysts have a more or less parallel arrangement.

\section{GEOCHRONOLOGY}

Analytical methods

Samples MLNB-733 (Dickie Brook quartz monzodiorite) and 97-DL-04 (Blue Mountain Granodiorite) were collected and analyzed by M.L. Bevier in 1988 and V. McNicoll in 1997, respectively, at the Geological Survey of Canada, Ottawa. Heavy mineral concentrates were prepared by standard crushing, grinding, Wilfley table, and heavy liquid techniques. Mineral separates were sorted by magnetic susceptibility using a Frantz isodynamic separator. Multigrain zircon fractions analyzed were very strongly air abraded following the method of Krogh (1982). U-Pb analytical methods were those outlined in Parrish et al. (1987). Treatment of analytical errors follows Roddick et al. (1987), with regression analysis modified after York (1969). Analytical results are presented in Table 1, where errors on the ages are reported at the $2 \sigma$ level, and displayed in the concordia plot (Figs. 5a, c).

Samples LB00-1 (Landry Brook quartz monzonite) and 09SHM-BR-50 (Dickie Brook quartz monzodiorite) were collected in the summer of 2009 by R.A. Wilson and S. McClaneghan, respectively, and analyzed by S. Kamo at the Jack Satterly Geochronology Laboratory of the University of Toronto. The samples were crushed, pulverized and 
passed over a Wilfley table. The resulting heavy mineral concentrates were re-processed on the Wilfley table until a significantly reduced sample size of $\sim 5-10 \mathrm{~g}$ was achieved (from rock samples weighing $\sim 8-12 \mathrm{~kg}$ ). The smaller heavy mineral concentrates were more rapidly processed through mineral separation procedures (i.e., magnetic separation and reduced volumes of methylene iodide of $\sim 2-8 \mathrm{ml}$ ) and no longer required the use of the heavy liquid "bromoform". $\mathrm{U}-\mathrm{Pb}$ analysis was by isotope dilution thermal ionization mass spectrometry methods (ID-TIMS) at the Jack Satterly Geochronology Laboratory of the University of Toronto.

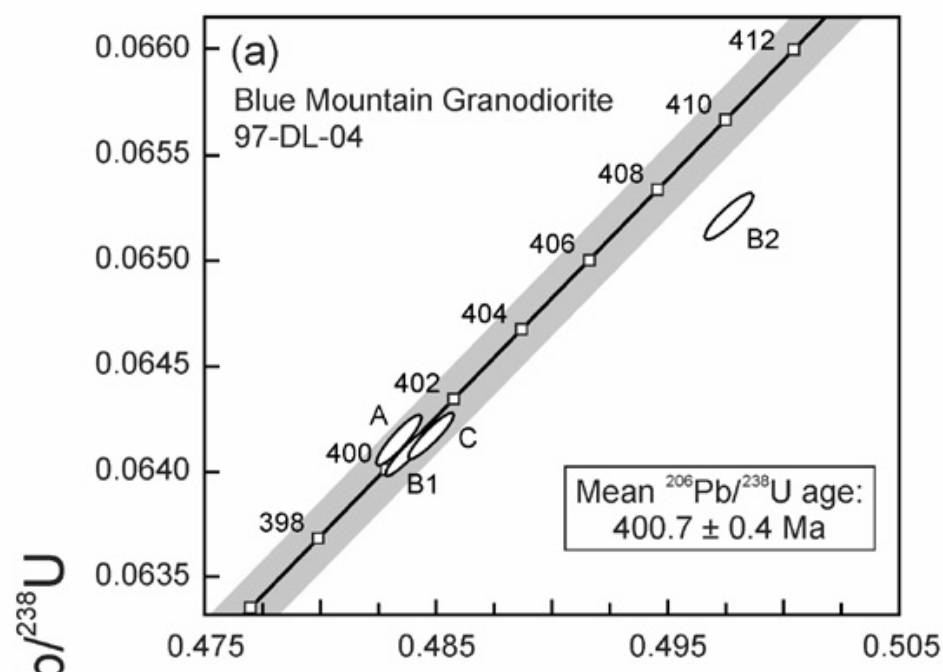

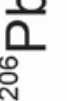

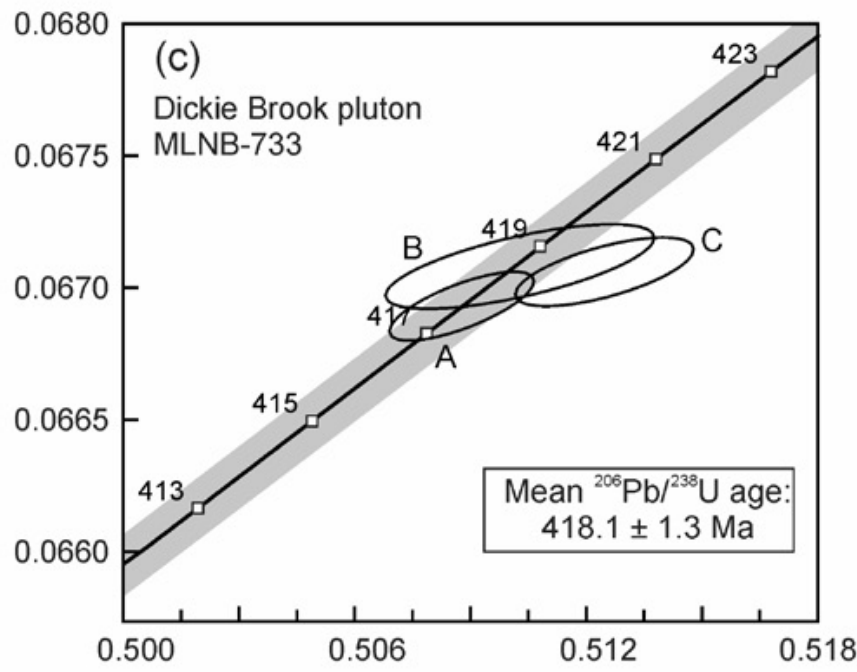

Prior to analysis, zircon crystals were thermally annealed and partially dissolved in HF (chemical abrasion), which has the advantage of penetratively removing alteration zones where $\mathrm{Pb}$ loss has occurred (Mattinson 2005). Grains were placed in a muffle furnace at $\sim 1000^{\circ} \mathrm{C}$ for 60 hours, followed by leaching in a $50: 50$ solution of $\mathrm{HF}$ and $6 \mathrm{~N} \mathrm{HCl}$ in Teflon dissolution vessels at $195^{\circ} \mathrm{C}$ for 16 hours. After selecting the zircons, their dimensions were measured, and the weights of each grain were calculated. The grains were washed in $8 \mathrm{~N} \mathrm{HNO}_{3}$ acid and ultra-clean acetone prior to dissolution. A ${ }^{205} \mathrm{~Pb}_{-}{ }^{233} \mathrm{U}_{-}{ }^{235} \mathrm{U}$ spike (ET535) was added to the Teflon
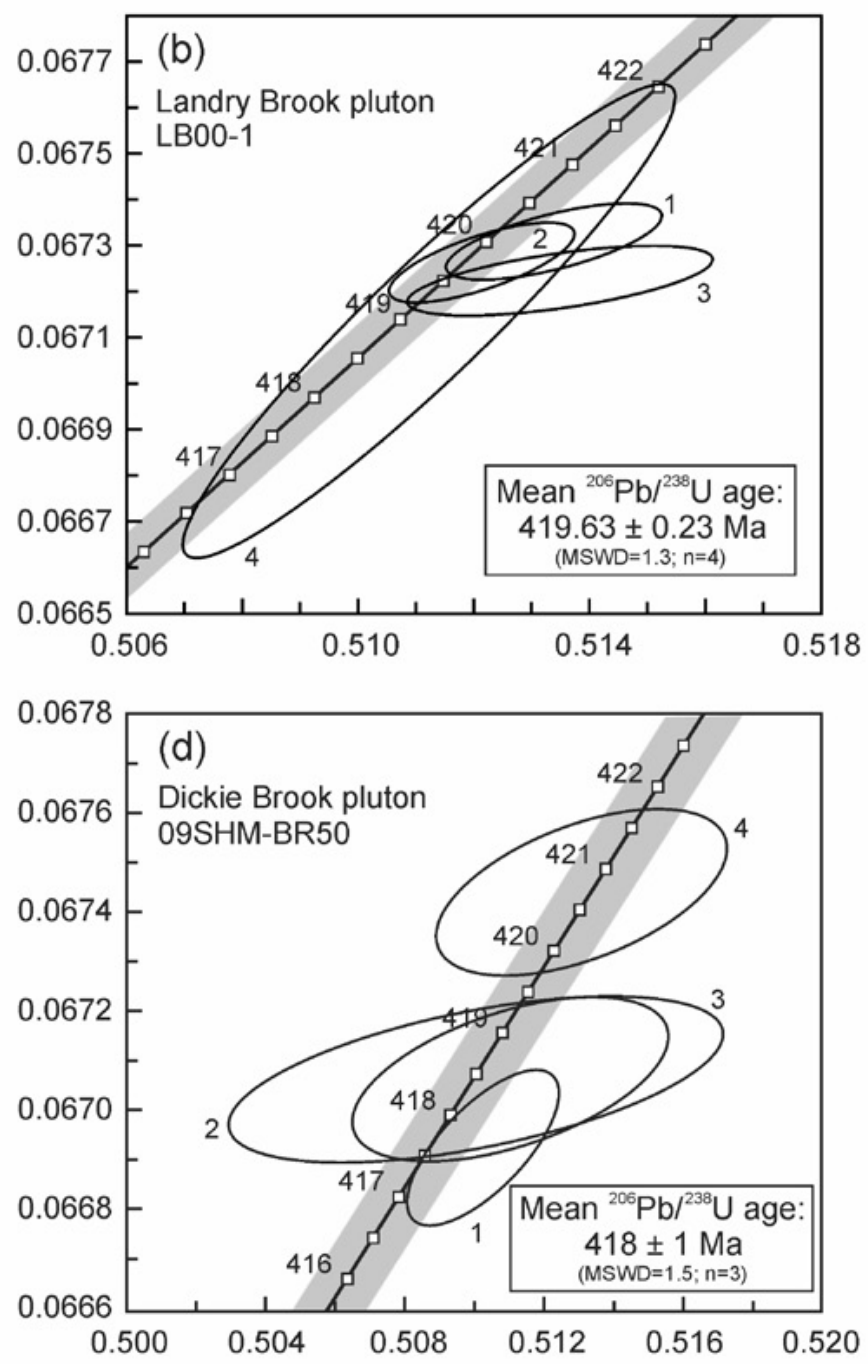

${ }^{207} \mathrm{~Pb} /{ }^{235} \mathrm{U}$

Fig. 5. Concordia diagrams for (a) Blue Mountain Granodiorite; (b) Landry Brook pluton; and (c) and (d) Dickie Brook pluton. Plotting and age calculations are from Isoplot/Ex 3.00 (Ludwig 2003). Sample locations are shown on Figure 1a. 
Table 1. U-Pb isotopic data for chemically abraded single zircon grains from samples 97-DL-04, LB00-1, MLNB-733, and 09SHM-BR-50.

\begin{tabular}{|c|c|c|c|c|c|c|c|c|c|c|c|c|c|c|c|c|c|c|c|}
\hline Sample & $\begin{array}{l}\text { Weight } \\
(\mu \mathrm{g})\end{array}$ & $\begin{array}{c}\mathrm{U} \\
(\mathrm{ppm})\end{array}$ & $\begin{array}{c}\mathrm{Pbtot}^{(\mathrm{a})} \\
(\mathrm{pg})\end{array}$ & $\begin{array}{c}\mathrm{Pb} \\
(\mathrm{ppm})\end{array}$ & $\mathrm{Th} / \mathrm{U}^{(\mathrm{b})}$ & $\begin{array}{l}\mathrm{Pb}^{(c)} \\
(\mathrm{pg})\end{array}$ & $\begin{array}{c}{ }^{206} \mathrm{~Pb} /{ }^{204} \mathrm{~Pb}^{(\mathrm{d})} \\
\text { measured }\end{array}$ & ${ }^{206} \mathrm{~Pb} /{ }^{238} \mathrm{U}^{(\mathrm{e})}$ & $2 \sigma$ & ${ }^{207} \mathrm{~Pb} /{ }^{235} \mathrm{U}^{(e)}$ & $2 \sigma$ & $\begin{array}{l}{ }^{206} \mathrm{~Pb} /{ }^{238} \mathrm{U} \\
\text { Age (Ma) }\end{array}$ & $2 \sigma$ & $\begin{array}{l}{ }^{207} \mathrm{~Pb} /{ }^{235} \mathrm{U} \\
\text { Age (Ma) }\end{array}$ & $2 \sigma$ & $\begin{array}{c}{ }^{207} \mathrm{~Pb} /{ }^{206} \mathrm{~Pb} \\
\text { Age (Ma) }\end{array}$ & $2 \sigma$ & $\% \operatorname{Disc}^{(f)}$ & $\begin{array}{l}\text { Error } \\
\text { Corr (g) }\end{array}$ \\
\hline \multicolumn{20}{|l|}{ 97-DL-04 } \\
\hline A & 61 & 127 & - & 8 & - & 3 & 9982 & 0.06415 & 0.00006 & 0.4833 & 0.0005 & 400.8 & 0.7 & 400.3 & 0.7 & 397.8 & 2.0 & -0.8 & 0.900 \\
\hline B1 & 70 & 140 & - & 9 & - & 5 & 8468 & 0.06409 & 0.00005 & 0.4838 & 0.0005 & 400.5 & 0.6 & 400.6 & 0.7 & 401.7 & 1.8 & 0.3 & 0.924 \\
\hline B2 & 40 & 138 & - & 9 & - & 4 & 5498 & 0.06521 & 0.00006 & 0.4976 & 0.0005 & 407.3 & 0.7 & 410.1 & 0.7 & 426.1 & 2.3 & 4.6 & 0.879 \\
\hline $\mathrm{C}$ & 64 & 155 & - & 10 & - & 8 & 4949 & 0.06417 & 0.00005 & 0.4848 & 0.0005 & 400.9 & 0.6 & 401.3 & 0.7 & 403.9 & 1.9 & 0.8 & 0.914 \\
\hline \multicolumn{20}{|l|}{ LB00-1 } \\
\hline 1 & 5.5 & 100 & - & 6.9 & 0.46 & 0.4 & 5661 & 0.067307 & 0.000068 & 0.5134 & 0.0015 & 419.91 & 0.41 & 420.7 & 1.0 & 425.2 & 5.4 & 1.3 & 0.669 \\
\hline 2 & 5.0 & 177 & - & 12.5 & 0.54 & 0.4 & 10119 & 0.067262 & 0.000072 & 0.5121 & 0.0013 & 419.64 & 0.43 & 419.9 & 0.9 & 421.3 & 4.3 & 0.4 & 0.714 \\
\hline 3 & 2.7 & 164 & - & 11.5 & 0.51 & 0.6 & 3401 & 0.067222 & 0.000062 & 0.5135 & 0.0022 & 419.40 & 0.38 & 420.8 & 1.4 & 428.5 & 8.3 & 2.2 & 0.608 \\
\hline 4 & 4.7 & 92 & - & 6.4 & 0.50 & 0.3 & 5780 & 0.067134 & 0.000421 & 0.5112 & 0.0035 & 418.87 & 2.54 & 419.3 & 2.3 & 421.6 & 5.0 & 0.7 & 0.944 \\
\hline \multicolumn{20}{|c|}{ MLNB-733 } \\
\hline A & 25 & 272 & - & 19 & - & 18 & 1525 & 0.06693 & 0.00007 & 0.50876 & 0.00094 & 417.6 & 0.8 & 417.6 & 1.3 & 417.5 & 5.8 & 0.0 & 0.732 \\
\hline B & 13 & 406 & - & 29 & - & 43 & 527 & 0.06708 & 0.00008 & 0.51027 & 0.00174 & 418.6 & 1.0 & 418.6 & 2.3 & 419.1 & 12.1 & 0.1 & 0.684 \\
\hline C & 16 & 279 & - & 19 & - & 17 & 1112 & 0.06706 & 0.00007 & 0.51246 & 0.00115 & 418.4 & 0.8 & 420.1 & 1.5 & 429.3 & 7.9 & 2.6 & 0.655 \\
\hline \multicolumn{20}{|c|}{ 09SHM-BR-50 } \\
\hline 1 & 6.3 & 108 & 47 & - & 0.52 & 0.5 & 6007 & 0.06693 & 0.00013 & 0.5103 & 0.0018 & 417.61 & 0.78 & 418.6 & 1.2 & 424 & 6 & 1.6 & 0.692 \\
\hline 2 & 2.6 & 161 & 29 & - & 0.47 & 0.9 & 2099 & 0.06707 & 0.00013 & 0.5111 & 0.0037 & 418.45 & 0.81 & 419.2 & 2.5 & 423 & 14 & 1.1 & 0.519 \\
\hline 3 & 2.1 & 157 & 22 & - & 0.41 & 1.4 & 1053 & 0.06706 & 0.00014 & 0.5101 & 0.0058 & 418.45 & 0.83 & 418.5 & 3.9 & 419 & 23 & 0.1 & 0.540 \\
\hline 4 & 3.1 & 104 & 22 & - & 0.42 & 0.7 & 2097 & 0.06744 & 0.00014 & 0.5131 & 0.0034 & 420.73 & 0.83 & 420.6 & 2.3 & 420 & 13 & -0.3 & 0.526 \\
\hline
\end{tabular}

Notes: ${ }^{(a)} \mathrm{Pbtot}$ is total amount of $\mathrm{Pb}$ excluding blank. ${ }^{(b)} \mathrm{Th} / \mathrm{U}$ calculated from radiogenic ${ }^{208} \mathrm{~Pb} /{ }^{206} \mathrm{~Pb}$ ratio and ${ }^{207} \mathrm{~Pb} /{ }^{206} \mathrm{~Pb}$ age assuming concordance. Correction for ${ }^{230} \mathrm{Th}$ disequilibrium in $206 / 238$ and $207 / 206$ assuming $\mathrm{Th} / \mathrm{U}$ of 4.2 in the magma. ${ }^{(c)} \mathrm{PbC}$ is total common $\mathrm{Pb}$ (assuming isotopic composition of laboratory blank for zircon and for titanite using Stacey and Kramers (1975) for intial $\mathrm{Pb}$ in excess of blank): laboratory $\mathrm{Pb}$ isotopic composition 206/204: 18.221; 207/204: 15.612; 208/204: 39.360; $2 \sigma$ errors of $1 \% .{ }^{(\mathrm{d})}$ Measured ratio for spike and fractionation only. ${ }^{(\mathrm{e})} \mathrm{Pb} / \mathrm{U}$ ratios are corrected for fractionation, common $\mathrm{Pb}$ in the spike, and blank. ${ }^{(\mathrm{f})}$ Disc is percent discordance for the given ${ }^{207} \mathrm{~Pb} /{ }^{206} \mathrm{~Pb}$ age. ${ }^{(\mathrm{g})}$ Error Corr is correlation coefficients of X-Y errors on the concordia plot. Decay constants are those of Jaffey et al. (1971).

dissolution capsules during sample loading. Zircon was dissolved using $\sim 0.10 \mathrm{~mL}$ of concentrated $\mathrm{HF}$ and $\sim 0.02 \mathrm{~mL}$ of $7 \mathrm{~N} \mathrm{HNO}_{3}$ in teflon bombs at $195^{\circ} \mathrm{C}$ (Krogh, 1973) for five days, and re-dissolved in $\sim 0.15 \mathrm{~mL}$ of $3 \mathrm{~N} \mathrm{HCl}$. Uranium and $\mathrm{Pb}$ were isolated from the zircon solutions using 50 microlitre anion exchange columns, dried in dilute $\mathrm{H} 3 \mathrm{PO} 4$ acid, and deposited onto outgassed rhenium filaments with silica gel (Gerstenberger and Haase 1997). Uranium and $\mathrm{Pb}$ were analyzed with a VG354 mass spectrometer using a Daly pulse-counting system. The dead time of the measuring system for $\mathrm{Pb}$ and $\mathrm{U}$ was $21.5 \mathrm{nsec}$. The mass discrimination correction for the Daly detector is constant at $0.05 \%$ /atomic mass unit. Amplifier gains and Daly characteristics were monitored using the SRM982 $\mathrm{Pb}$ standard. Thermal mass discrimination corrections are $0.10 \%$ /atomic mass unit. The total amount of common $\mathrm{Pb}$ for each analysis (Table 1) was attributed to laboratory $\mathrm{Pb}$, thus no correction for initial common $\mathrm{Pb}$ from geological sources was made.

\section{Results}

In geologically young zircons, the ${ }^{238} \mathrm{U} /{ }^{206} \mathrm{~Pb}$ dating system is the most reliable and precise because of the much greater abundance of ${ }^{238} \mathrm{U}$. Therefore, the results (Table 1 and Fig. 5) presented herein refer exclusively to the ${ }^{206} \mathrm{~Pb} /{ }^{238} \mathrm{U}$ ages.

Four multigrain zircon fractions were analyzed in sample 97-DL-04, representing the various zircon morphologies in the sample, including equant multifaceted crystals (fraction A), prismatic crystals with aspect ratios of about 2:1 (fractions B1 and B2), and elongate, needle- like grains (fraction C). Most of the zircon grains analyzed contain minor fluid inclusions. Three of the analyses overlap and are near-concordant (Fig. 5a). Analysis B2 contains an inherited component and is not included in the age calculation. A weighted average of the ${ }^{206} \mathrm{~Pb} /{ }^{238} \mathrm{U}$ ages of fractions A, B1, and C is calculated to be $400.7 \pm 0.4 \mathrm{Ma}$ (Fig. 5a), which is interpreted to be the crystallization age of the Blue Mountain Granodiorite.

In sample LB00-1 from the Landry Brook pluton, abundant zircons are euhedral, sharply-facetted, pink, multi-facetted to 2:1 prismatic, fresh and gem-like, and contain abundant bubble-like melt inclusions. The $\mathrm{U}-\mathrm{Pb}$ data for four, single, chemically-abraded zircon crystals give concordant, highly reproducible data. The weighted mean ${ }^{206} \mathrm{~Pb} /{ }^{238} \mathrm{U}$ age is $419.63 \pm 0.23 \mathrm{Ma}$ (Fig. 5b) and this is interpreted as the best age estimate for the Landry Brook pluton, which is significantly older that the previously reported age of $370 \pm 30 \mathrm{Ma}$ (whole-rock Rb-Sr; Stewart 1979). It is also older than the spatially related Blue Mountain Granodiorite $(401.7 \pm 0.4 \mathrm{Ma})$.

Two independent age analyses were done at the same location (Fig. 2a) on the Dickie Brook pluton. A comparison of sample MLNB-733 with the recently collected sample 09SHM-BR50 enabled us to verify the accuracy of the original age determination. The zircons analyzed in sample MLNB-733 were pale yellow, clear, stubby to elongate square prisms with simple terminations. Both samples show three-data-point clusters with weighted mean ${ }^{206} \mathrm{~Pb} /{ }^{238} \mathrm{U}$ ages of $418.1 \pm 1.3 \mathrm{Ma}$ (Fig. 5c) and $418 \pm 1 \mathrm{Ma}$ (Fig. 5d), respectively. In sample 09SHM-BR50, the fourth data point is older and plots outside the error range of the cluster, having $\mathrm{a}^{206} \mathrm{~Pb} /{ }^{238} \mathrm{U}$ age of $420.7 \pm 0.8 \mathrm{Ma}$. This grain is interpreted as having crystallized $2-3$ my prior to the granite, and was 
incorporated into the granite magma source or during emplacement of the granite body. Therefore, the age of the granite is interpreted to be $418 \pm 1 \mathrm{Ma}$, making it, within error, coeval with the Landry Brook pluton.

\section{GEOCHEMISTRY}

\section{Introduction}

Forty samples from the Landry Brook and Dickie Brook plutons, the Charlo plutonic suite, and Blue Mountain Granodiorite were analysed for major and trace elements, including rare-earth elements (Appendix 2 and 3) at ACME Analytical Laboratories Ltd., Vancouver, Canada. Lithologically homogeneous samples (i.e., barren of enclaves) were collected with an effort to ensure that the freshest, least altered samples were taken. However, the spatial distribution of collected samples is, in general, dependant on the available exposed bedrock.

The purpose of this section is to describe the chemical characteristics of the plutons based on these data. In order to compare the chemical characteristics of the Landry Brook and Dickie Brook plutons and the Charlo plutonic suite, all of the samples are plotted together on Harker variation diagrams. The geochemical data of Whalen (1993) also are included on these diagrams to increase the amount of data, and include 6 samples from the Landry Brook pluton, 4 samples from the Dickie Brook pluton, and 4 samples from the Charlo plutonic suite.

\section{Major Element Compositions}

In the Landry Brook pluton and Charlo plutonic suite, gabbro/quartz diorite and diabase have $\mathrm{SiO}_{2}$ concentrations of 47-50 wt. \% (Fig. 6), and a gap in $\mathrm{SiO}_{2}$ separates those rocks from intermediate to felsic rocks, which vary from 58 to 78 wt. \% $\mathrm{SiO}_{2}$. Samples from the Dickie Brook pluton have a continuous silica spectrum ranging from $50 \%$ to $72 \%$. Overall, $\mathrm{TiO}_{2}, \mathrm{Al}_{2} \mathrm{O}_{3}, \mathrm{Fe}_{2} \mathrm{O}_{3}{ }^{\mathrm{t}}, \mathrm{MgO}$, and $\mathrm{CaO}$ show similar negative correlation with $\mathrm{SiO}_{2}$ in all three plutons (Fig. 6), consistent with decreasing abundances of ferromagnesian minerals, plagioclase, titanite, and magnetite. Amounts of $\mathrm{TiO}_{2}, \mathrm{Fe}_{2} \mathrm{O}_{3}{ }^{\mathrm{t}}, \mathrm{MgO}$, and $\mathrm{CaO}$ (Figs. 6a, c-e) are higher in gabbro/quartz diorite samples than in samples from the intermediate-felsic units, reflecting their greater abundance of ferromagnesian minerals and calcic plagioclase. Although they vary little in $\mathrm{SiO}_{2}$, the gabbro/quartz diorite samples show a wide range in most other major oxides including $\mathrm{TiO}_{2}, \mathrm{Al}_{2} \mathrm{O}_{3}, \mathrm{Fe}_{2} \mathrm{O}_{3}{ }^{\mathrm{t}}, \mathrm{MgO}$, and $\mathrm{CaO}$ (Figs. 6a-e), consistent with the varying abundances of clinopyroxene, amphibole, plagioclase, opaque minerals, and titanite observed in these samples.
Both $\mathrm{K}_{2} \mathrm{O}$ and $\mathrm{Na}_{2} \mathrm{O}$ (Figs. 6f, g) show positive correlation with $\mathrm{SiO}_{2}$, consistent with the absence of $\mathrm{K}$-bearing minerals (e.g., $\mathrm{K}$-feldspar and biotite) in the mafic rocks. $\mathrm{Na}_{2} \mathrm{O}$ shows an increase and then a decrease after about $65 \% \mathrm{SiO}_{2}$, which could be linked to fractionation of increasingly Na-rich plagioclase as the magma evolved.

In samples from the Landry Brook pluton and Charlo plutonic suite, a gap in $\mathrm{MgO}$ of about 2-3 wt. \% separates mafic samples and intermediate-felsic samples (Fig. 6d). For example, the abundance of Mg-rich clinopyroxene in the gabbro compared to its minor presence in the quartz monzodiorite in samples from the Charlo plutonic suite is consistent with this gap, which does not exist in the $\mathrm{Fe}_{2} \mathrm{O}_{3}{ }^{\mathrm{t}}$ data (Fig. 6c). Samples from the hornblende dacite porphyry dyke in the Charlo plutonic suite and porphyritic granodiorite in the Blue Mountain Granodiorite tend to diverge from the trends defined by samples from the other units, with slightly higher $\mathrm{Al}_{2} \mathrm{O}_{3}, \mathrm{CaO}$, and $\mathrm{MgO}$ and lower $\mathrm{TiO}_{2}, \mathrm{Fe}_{2} \mathrm{O}_{3}{ }^{\mathrm{t}}$, and $\mathrm{K}_{2} \mathrm{O}$. The quartz rhyolite porphyry in the Charlo plutonic suite is the most felsic unit in the study area, and has very low abundances of all of these components. Overall, $\mathrm{P}_{2} \mathrm{O}_{5}$ shows a wide spread in the more mafic samples, linked to modal variations in apatite content, and then decreases in the felsic samples, likely as a result of apatite fractionation, perhaps as inclusions in the fractionating ferromagnesian minerals

Collectively, samples from the four intermediate-felsic units show negative correlation of $\mathrm{Al}_{2} \mathrm{O}_{3}, \mathrm{TiO}_{2}, \mathrm{Fe}_{2} \mathrm{O}_{3}{ }^{\mathrm{t}}, \mathrm{MgO}$, $\mathrm{MnO}$, and $\mathrm{CaO}$ with $\mathrm{SiO}_{2}$, consistent with fractionation of ferromagnesian minerals and calcic plagioclase. The mafic units in the Landry Brook pluton and Charlo plutonic suite are similar, except that the gabbro in the Charlo plutonic suite contains much lower $\mathrm{CaO}$ (Fig. 6e) and higher $\mathrm{Na}_{2} \mathrm{O}$ and $\mathrm{P}_{2} \mathrm{O}_{5}$ (Figs. 6f, h). Overall, the samples from all units are similar, although diorite/quartz diorite from the Dickie Brook pluton shows the greatest deviation from the norm.

\section{Trace and Rare-Earth Element Compositions}

Ratios of $\mathrm{Zr} / \mathrm{TiO}_{2}$ show a stronger variation than $\mathrm{Nb} / \mathrm{Y}$ (Fig. 7a) with lower $\mathrm{Zr} / \mathrm{TiO}_{2}$ values for the mafic units, consistent with the negative correlation of $\mathrm{TiO}_{2}$ and $\mathrm{SiO}_{2}$ (Fig. 6a). These ratios plotted on a volcanic rock-equivalent discrimination diagram (Fig. 7a) are more or less consistent with the names determined using modal mineralogy. High $\mathrm{Zr} / \mathrm{Y}$ and $\mathrm{Th} / \mathrm{Yb}$ ratios (Fig. $7 \mathrm{~b}$ ) associate the rocks with calc-alkaline affinity, consistent with the range rock types present. The rhyolite porphyry plots outside the main data cluster due to high values of $\mathrm{Y}$ relative to $\mathrm{Zr}$. This feature is also shown using $\mathrm{Zr} / \mathrm{Hf}$ against $\mathrm{Zr}$ (Fig. 7c) with high $\mathrm{Hf}$ values relative to $Z r$. Although most of the units are shown in the Chondrite and Cumulate residue fields, the rhyolite 

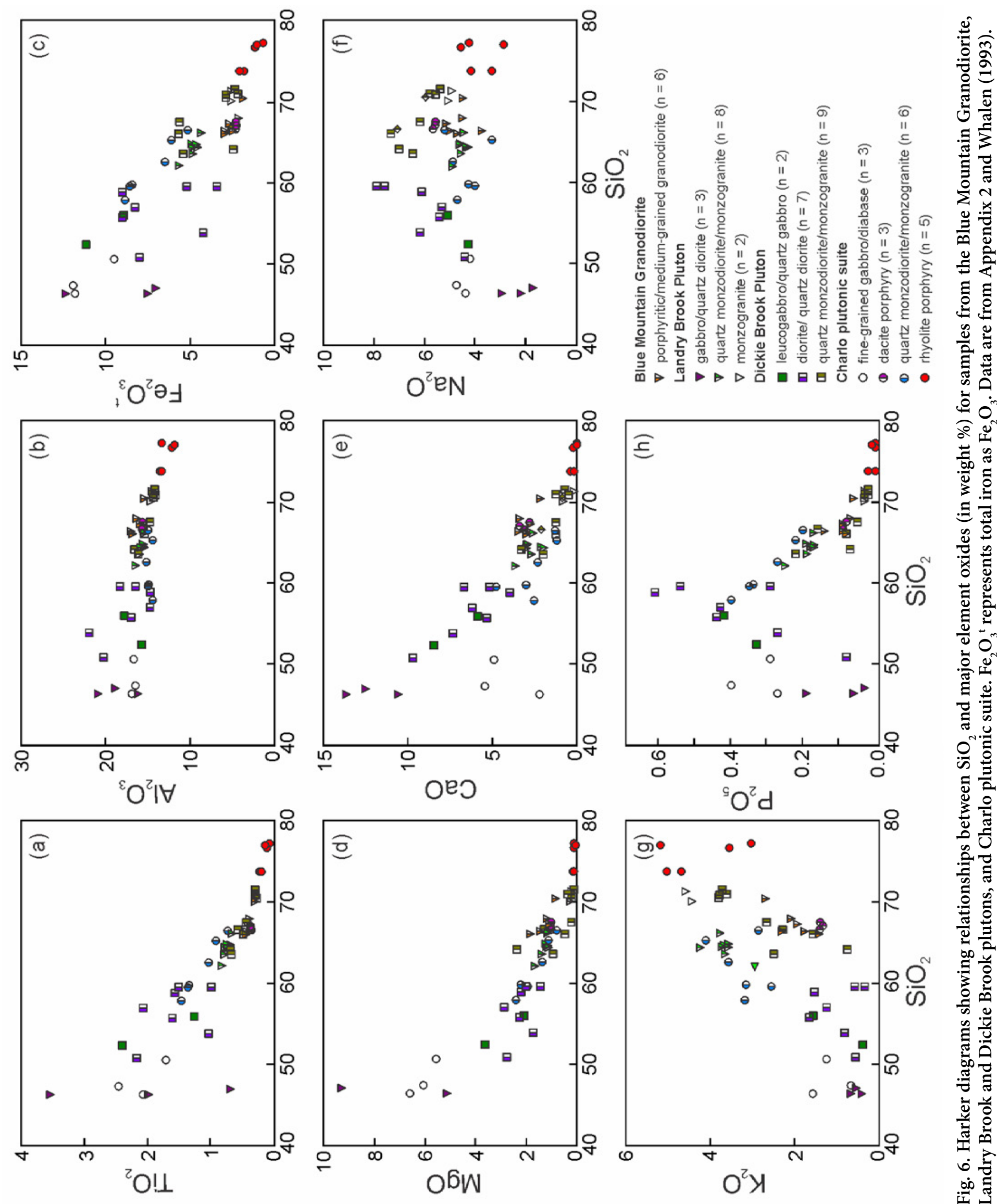

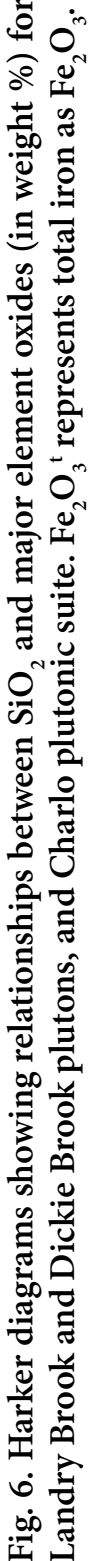


porphyry from the Charlo plutonic suite is more likely to result from the melting of continental crust. La/Yb ratios (Fig. 7d) for all units are similar $(<14)$, whereas the Blue Mountain Granodiorite and Charlo dacite porphyry have $\mathrm{La} / \mathrm{Yb}$ ranging from 22 to 48 , suggesting that they were generated from a genetically unrelated source that probably contained garnet (Thirlwall et al. 1994).

Comparing the chondrite-normalized REE diagrams from pluton to pluton (Figs. 8a-c), the Blue Mountain Granodiorite (Fig. 8a) and dacite porphyry of the Charlo plutonic suite (Fig. 8c) are strikingly similar, with significantly lower values in heavy REE and higher La/Yb ratios (Fig. 7c). The gabbro/quartz diorite samples from the Landry Brook pluton tend to have lower total REE than the other units (Fig. 8a), including lower LREE and higher heavy REE, probably linked to the abundance of apatite and other accessory minerals. The REE pattern for the rhyolite porphyry from the Charlo plutonic suite also shows elevated heavy REE (Fig. 8c), as do the two samples from the monzogranite unit in the Landry Brook pluton (Fig. 8a).

Similar sloping profiles of decreasing light to heavy REE's for the quartz monzodiorite/monzogranite of the
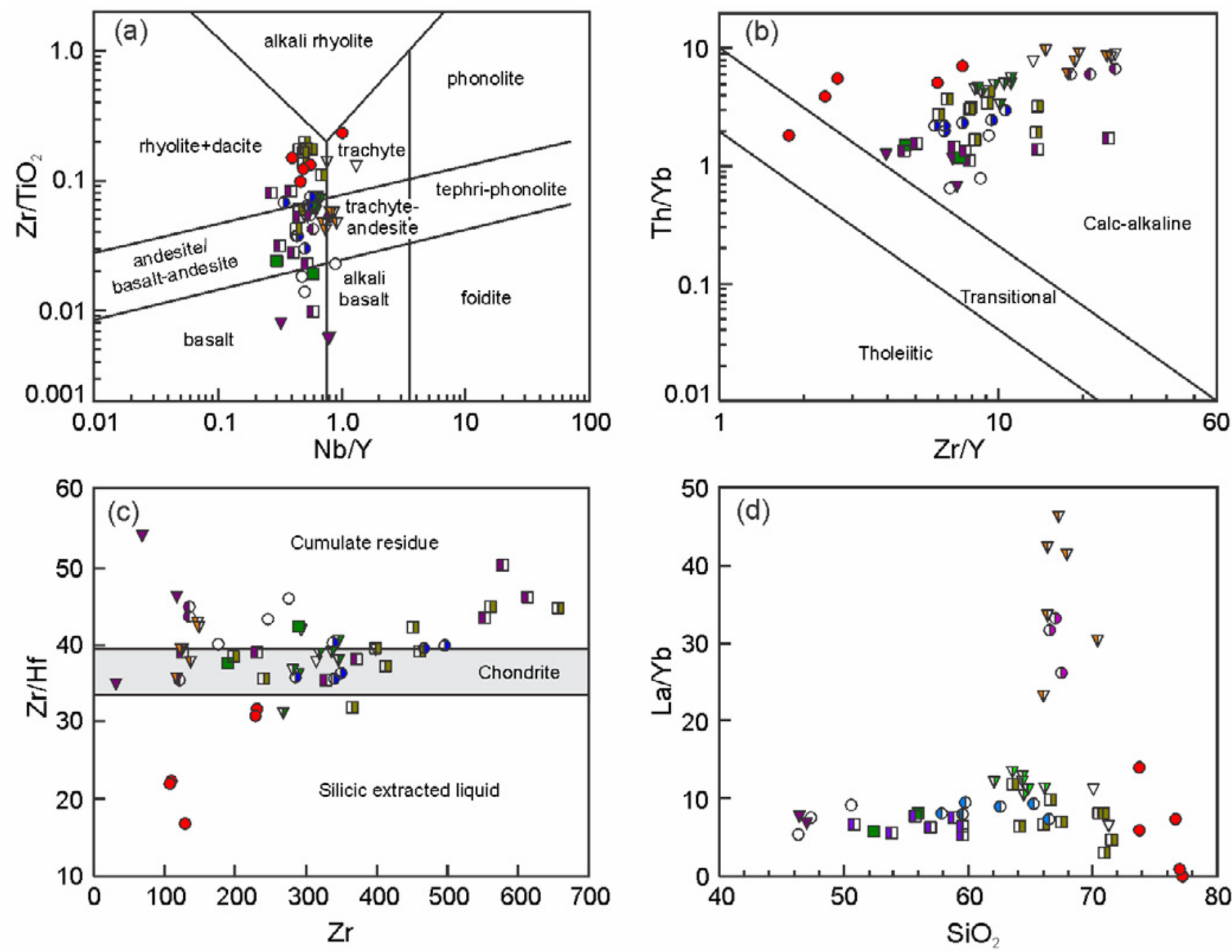

Fig. 7. (a) Volcanic equivalent discrimination diagram of $\mathrm{Zr} / \mathrm{TiO}_{2}$ against $\mathrm{Nb} / \mathrm{Y}$ for samples from the Blue Mountain Granodiorite, Landry Brook and Dickie Brook plutons, and Charlo plutonic suite (fields from Pearce 1996b). (b) Plot of $\mathrm{Th} / \mathrm{Yb}$ against $\mathrm{Zr} / \mathrm{Y}$ (after Ross and Bedard 2009). (c) Plot of $\mathrm{Zr} / \mathrm{Hf}$ against $\mathrm{Zr}$ (in ppm); $\mathrm{Zr} / \mathrm{Hf}$ values at or above Chondrite are cumulates and those that fall below are extracted silicic liquids (Deering and Bachmann 2010). (d) Plot of La/Yb ratio against $\mathrm{SiO}_{2}$ (in weight \%). Symbols are as in Fig. 6. 

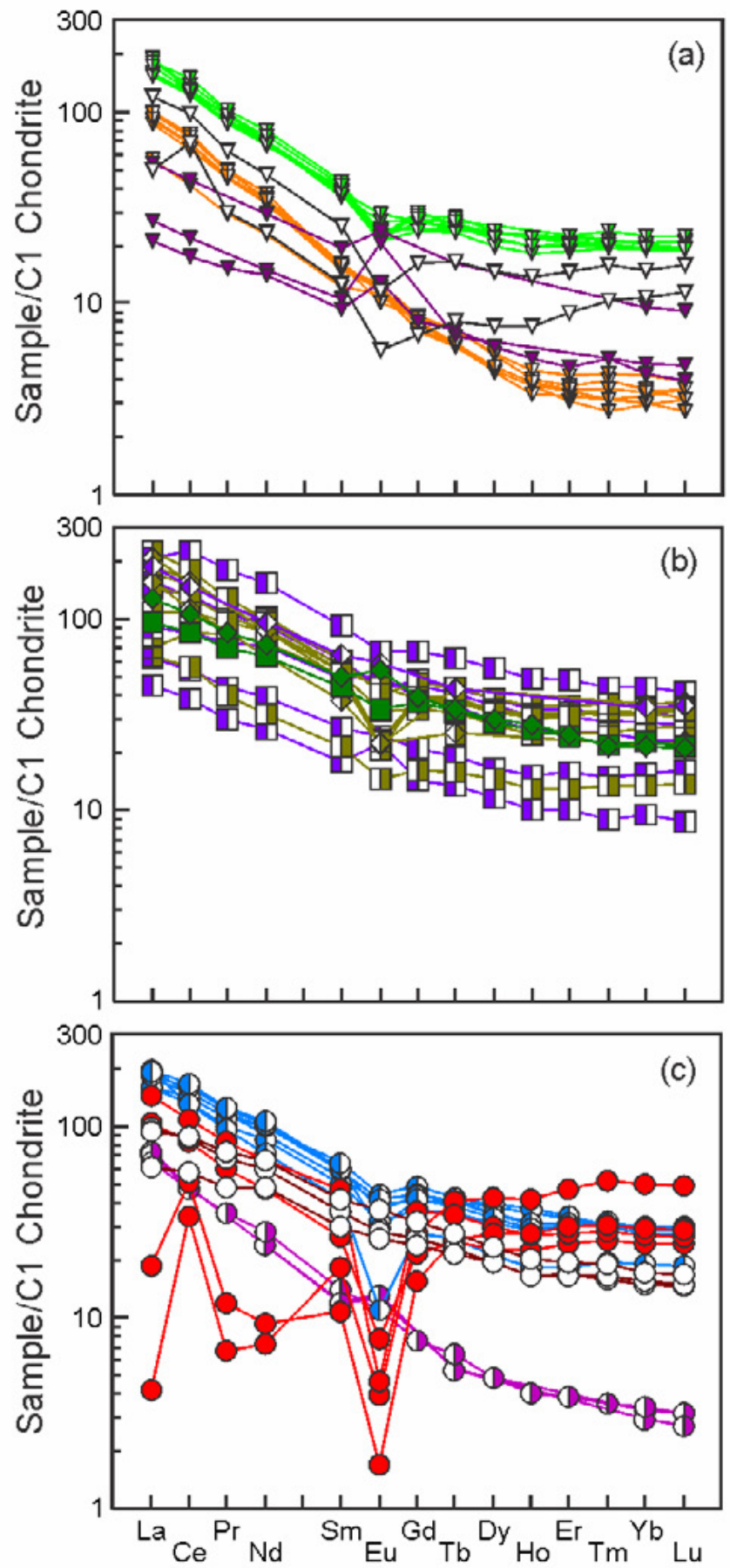

Fig. 8. Chondrite-normalized REE diagram for (a) Landry Brook pluton and Blue Mountain Granodiorite, (b) Dickie Brook pluton, and (c) Charlo plutonic suite. Chondritenormalizing values are from Sun and McDonough (1989). Symbols are as in Fig. 6.
Landry Brook pluton, all of the units of the Dickie Brook pluton, and the quartz monzodiorite/monzogranite of the Charlo plutonic suite suggest that all of these units are co-magmatic, which is supported by the similarities on variation and ratio diagrams (Figs. 6-8).

\section{CHEMICAL AFFINITY AND TECTONIC SETTING}

Petrographic and chemical characteristics described in previous sections suggest that most of the units in the Landry Brook and Dickie Brook plutons and Charlo plutonic suite are comagmatic and potentially linked by fractional crystallization, predominantly of plagioclase and amphibole. All three plutons show calc-alkaline trends, although some samples show moderate iron enrichment and plot on or slightly above the tholeiitic/calc-alkaline dividing line on an AFM diagram (Fig. 9a). This diagram illustrates the bimodality of the Landry Brook pluton compared to the more continuous trends in the other two plutons; the Landry Brook gabbros may therefore represent part of an unrelated but coeval suite that appears to be tholeiitic based on the AFM diagram (Fig. 9a). The Blue Mountain Granodiorite and the dacite porphyry from the Charlo plutonic suite are also calc-alkaline, but have relatively higher $\mathrm{MgO}$ and hence form a cluster distinct from the trends of the other plutons (Fig. 9a). Given the much younger age obtained for the Blue Mountain Granodiorite, its close geochemical similarity with the dacite porphyry suggests that the latter is probably also Devonian.

All samples with more than $60 \% \mathrm{SiO}_{2}$ are metaluminous to peraluminous based on the $\mathrm{SiO}_{2}$ vs. A/CNK classification diagram for granitoid rocks (Fig. 9b). The Landry Brook pluton and Charlo plutonic suite straddle the metaluminousperaluminous fields, although none of these rocks have mineralogical characteristics of peraluminous granite (such as primary muscovite or other Al-rich minerals) and the apparently peraluminous character is probably related to alkali mobility. Hornblende fractionation could be another factor contributing to the peraluminous character (Cawthorn and Brown 1976). All samples of altered rhyolite porphyry from the Charlo plutonic suite are peraluminous, whereas the Dickie Brook pluton, in contrast, is entirely metaluminous. The Blue Mountain Granodiorite is somewhat more peraluminous than all other units, with higher alumina relative to soda and potash; however, the Charlo dacite porphyry is metaluminous (Fig. 9b).

On Rb vs. $\mathrm{Y}+\mathrm{Nb}$ and $\mathrm{Hf}-\mathrm{Rb}-\mathrm{Nb}$ tectonic discrimination diagrams for granitoid rocks (Figs. 9c, d), intermediate and felsic rocks straddle the volcanic-arc and within-plate fields, with most points falling within the circular field for post-collisional granitoids (Pearce 1996a). The Dickie Brook quartz monzodiorites and monzogranites display the 

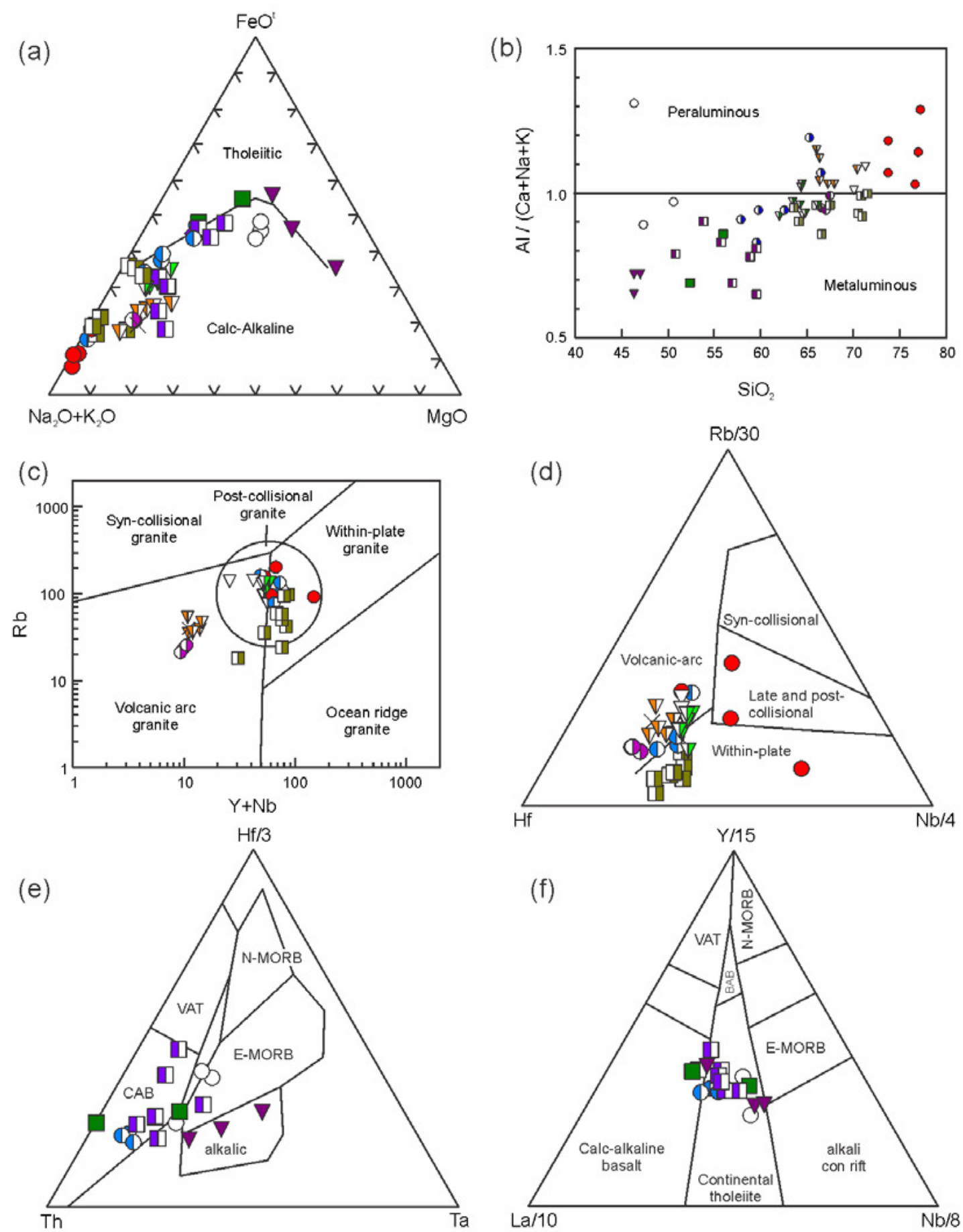

Fig. 9. Chemical affinity diagrams for samples from Blue Mountain Granodiorite, Landry Brook and Dickie Brook plutons, and Charlo plutonic suite. (a) AFM diagram. (b) Molar $\mathrm{Al}_{2} \mathrm{O}_{3} /\left(\mathrm{CaO}+\mathrm{Na}_{2} \mathrm{O}+\mathrm{K}_{2} \mathrm{O}\right)$ against $\mathrm{SiO}_{2}$ (in weight \%). Intermediatefelsic samples (>60 wt. \% $\mathrm{SiO}_{2}$ ) plotted on tectonic setting discrimination diagrams for granitoid rocks with: (c) Rb against $\mathrm{Y}+\mathrm{Nb}$ diagram and (d) $\mathrm{Hf}-\mathrm{Rb}-\mathrm{Nb}$ diagram. Tectonic setting discrimination diagrams for mafic-intermediate $(<60 \%$ $\mathrm{SiO}_{2}$ ) samples with: (e) Th-Hf-Ta diagram and (f) La-Y-Nb diagram. Tholeiitic/calc-alkaline dividing line in (a) is from Irvine and Baragar (1971); Fields in (b) are from Maniar and Piccoli (1989); Fields in (c) are from Pearce et al. (1984) with addition of the post-collisional field from Pearce (1996a); Fields in (d) are from Harris et al. (1986); Fields in (e) are from Wood (1980); Fields in (f) are from Cabanis and Lecolle (1989). Abbreviations: CAB, calc-alkaline basalt; VAT, volcanic arc tholeiite; $\mathrm{N}$ - and E-MORB, normal and enriched mid-ocean-ridge basalt; alkalic, alkali basalt; BAB, back-arc basin basalt; CON, continental tholeiite; D-arc, depleted arc; OIB, ocean island basalt. Symbols are as in Fig. 6. 
most prominent within-plate character on both diagrams, whereas the Blue Mountain Granodiorite and Charlo dacite porphyry have lower $\mathrm{Y}$ and $\mathrm{Nb}$ and plot in the field of volcanic-arc granites (Figs. 9c, d). On average, all samples are more typical of I-type granitoid rocks than A-type granitoids (Fig. 10). Looking at just the mafic rocks from all three plutons, most samples from the Dickie Brook pluton plot in the calk-alkaline field on a Th-Hf-Ta diagram (Fig. 9e), whereas samples from the Landry Brook pluton plot in the alkalic field. Quartz monzodiorite in the Charlo plutonic suite plots in the calc-alkalic basalt field, although related gabbros overlap two or more fields (Fig. 9e). On a La-Y-Nb plot (Fig. 9f) most mafic rocks from all plutons plot in the continental tholeiite field.

Oxygen and $\mathrm{Sm}-\mathrm{Nd}$ isotope data for these plutons were reported by Whalen (1993). The $\delta^{18} \mathrm{O}_{\mathrm{wR}}$ values are 6.6 in a sample from the Dickie Brook pluton, 6.5 in a sample from the Landry Brook pluton, and 7.4 in a sample from the Charlo plutonic suite (Whalen 1993). All are within the range expected of granitoid rocks derived from mantle-like sources (Taylor 1988). The $\varepsilon_{\mathrm{Nd}}$ isotopic signatures of these rocks are relatively high $(+1.2,+2.0$, and +4.5$)$ which suggests mainly a mantle source but with some crustal interaction (Whalen 1993). Overall, the values are higher than $\varepsilon_{\mathrm{Nd}}$ signatures reported from Ganderia in Newfoundland, which tend to be negative (e.g., Kerr et al. 1995; Whalen et al. 1994).

Overall, the tectonic setting for these plutons is most likely within-plate but the data such as high $\mathrm{Zr} / \mathrm{Y}$ and $\mathrm{Th} / \mathrm{Yb}$ ratios indicate a subduction influence, such as in a back-arc setting. Their chemical characteristics are explored in more

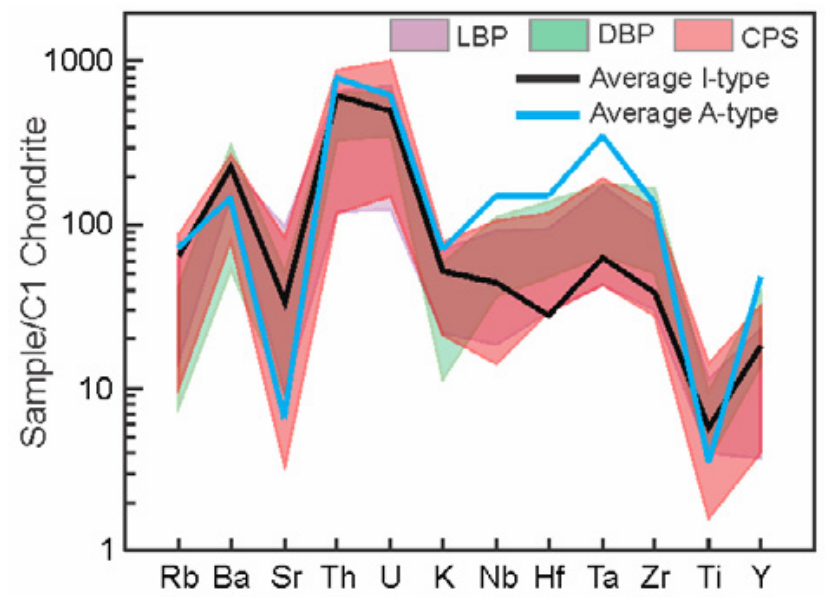

Fig. 10. Multi-element variation diagram for intermediatefelsic samples from the Silurian plutons of this study compared to average I-type and A-type compositions from Whalen et al. (1987). Abbreviations: LBP, Landry Brook pluton; DBP, Dickie Brook pluton; CPS, Charlo plutonic suite. Chondrite-normalizing values are from Sun and McDonough (1989). detail below, together with data from the associated and more voluminous volcanic rocks of the Dickie Cove Group.

\section{RELATIONSHIPS WITH THE HOST ROCKS}

The host rocks of the Landry Brook and Dickie Brook plutons, and part of the Charlo plutonic suite, are the Bryant Point Formation and overlying Benjamin Formation of the Dickie Cove Group (Fig. 1), consisting mainly of subaerial mafic and felsic volcanic rocks, respectively (Walker and McCutcheon 1995; Wilson and Kamo 2012). A rhyolite flow from near the base of the Bryant Point Formation has yielded a U-Pb (zircon) age of $422.3 \pm 0.3 \mathrm{Ma}$, whereas a U-Pb (zircon) age of $419.7 \pm 0.3 \mathrm{Ma}$ was obtained for rhyolite at the top of the Benjamin Formation (Wilson and Kamo 2012). Emplacement of the Landry Brook quartz monzodiorite at $419.63 \pm 0.23 \mathrm{Ma}$ (Fig. 5) was therefore essentially coeval with cessation of felsic volcanism. Emplacement of the Dickie Brook quartz monzodiorite/monzogranite occurred shortly thereafter, at $418 \pm 1 \mathrm{Ma}$ (Fig. 5).

Mafic volcanic rocks of the Bryant Point Formation show chemical similarities to gabbro and leucogabbro $(<52$ $\% \mathrm{SiO}_{2}$ ) from the Landry Brook and Dickie Brook plutons and Charlo plutonic suite. Like the plutons, the Bryant Point Formation is mainly calk-alkaline but straddles the boundary with the tholeiite field (Fig. 11a). On a multielement spidergram (Fig. 11b), the mafic samples show similar patterns, with negative anomalies in $\mathrm{Cs}, \mathrm{Rb}, \mathrm{K}$, and a positive anomaly in Sr. REE patterns of volcanic and plutonic rocks are similar, with most showing parallel patterns and continuous depletion from LREE to HREE, with the exception of slight positive Eu anomalies in a few samples (Fig. 11c). On a Hf-Th-Ta diagram (Fig. 11d), most samples span the calc-alkalic basalt to within-plate tholeiite/ E-MORB fields; only gabbros from the Landry Brook pluton plot in the alkaline basalt field. However, most volcanic and plutonic rocks plot in the within-plate field on a Ti-Zr-Y diagram (Fig. 11e), and in a cluster that overlaps the withinplate and volcanic-arc fields on a $\mathrm{Zr}-\mathrm{Y}-\mathrm{Nb}$ diagram (Fig. 11f). In general, these strong similarities are consistent with the volcanic and mafic plutonic rocks being co-magmatic and formed in a continental within-plate setting as suggested previously by Dostal et al. (1989).

Late Silurian felsic volcanic rocks of the Benjamin Formation also have chemical similarities to felsic intrusive rocks of all three plutons. Plotted together on a multielement variation diagram normalized to primitive mantle, the volcanic and plutonic rocks show similar patterns, including pronounced negative $\mathrm{Ba}, \mathrm{Nb}, \mathrm{Sr}, \mathrm{Eu}$, and $\mathrm{Ti}$ anomalies (Fig. 12a). The REE profiles are also similar, with strong negative Eu anomalies, although the volcanic rocks tend to have higher REE overall (Fig. 12b). In terms of tectonic setting, both volcanic and plutonic rocks plot in 
(a)
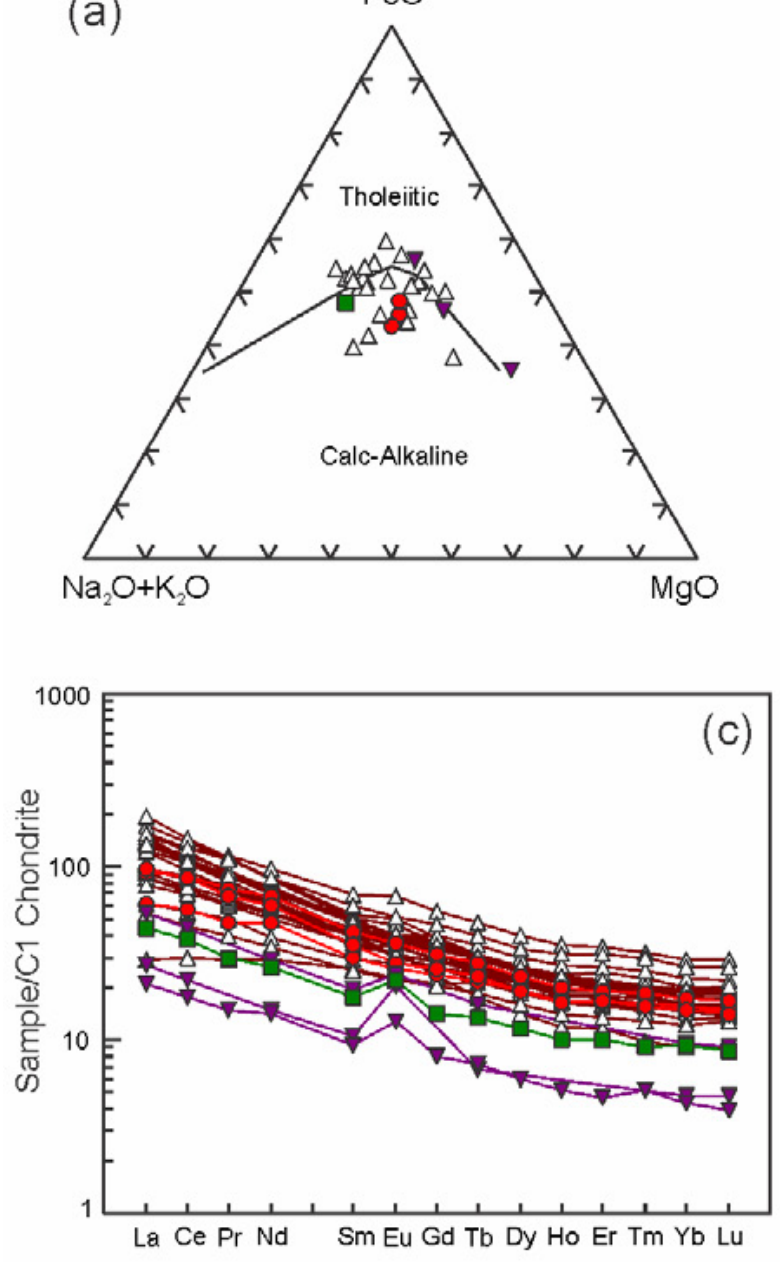

(e)

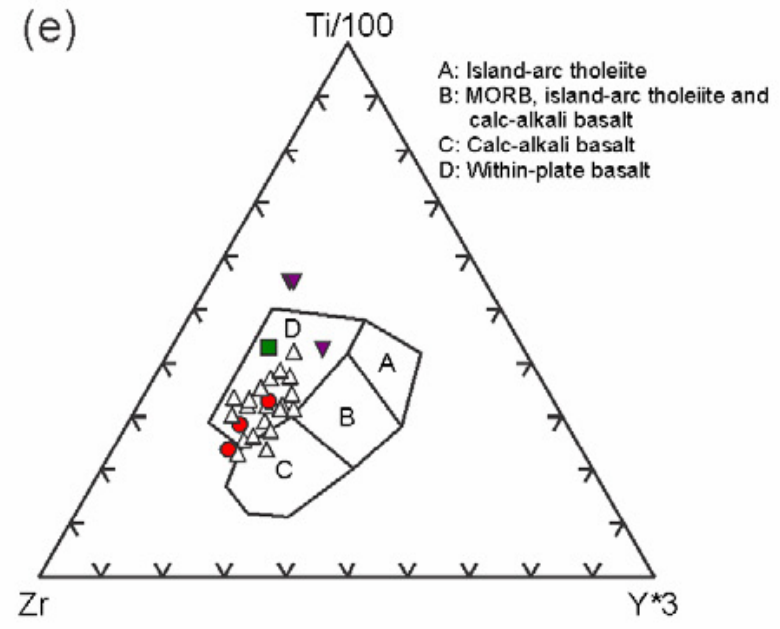

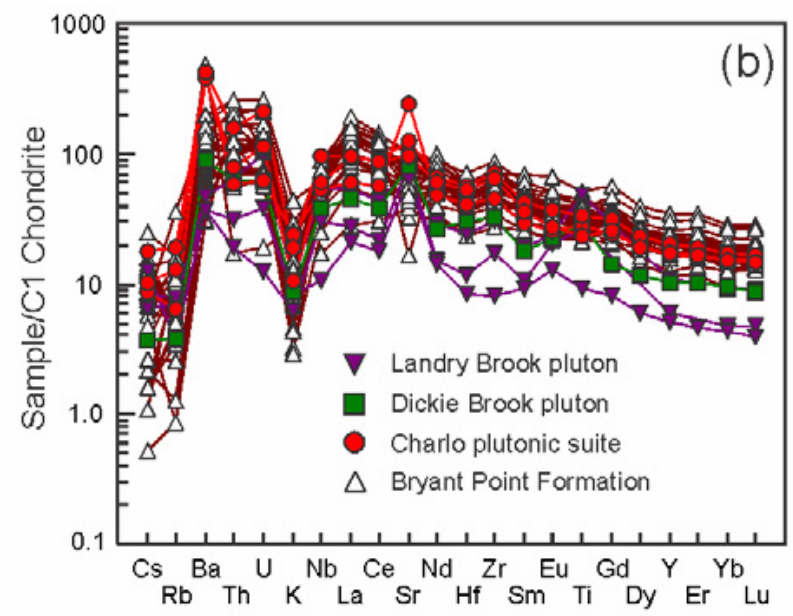
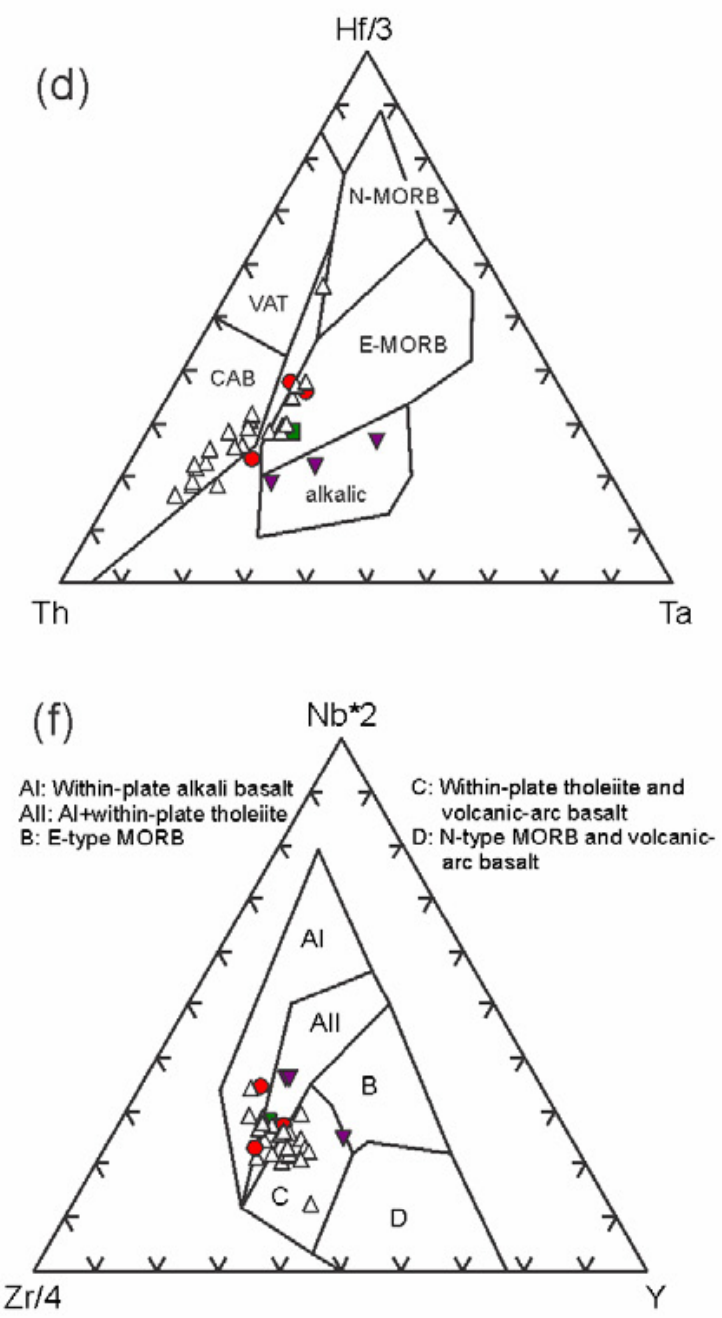

Fig. 11. Comparision between mafic $\left(<52 \% \mathrm{SiO}_{2}\right)$ plutonic and volcanic units. (a) AFM diagram with the tholeiitic/calcalkaline dividing line of Irvine and Baragar (1971). (b) Extended multi-element spider diagram with normalizing values from Sun and McDonough (1989). (c) Chondrite-normalized REE diagram with normalizing values from Sun and McDonough (1989). (d) Th-Hf-Ta ternary diagram with fields from Wood et al. (1979). (e) $\mathrm{Zr}$-Ti-Y tectonic discrimination diagram with fields from Pearce and Cann (1973). (f) Zr-Nb-Y tectonic discrimination diagram with fields from Meschede (1986). Data for the Bryant Point Formation are from R. Wilson (unpublished data). Symbols are shown in Fig. 11b. 

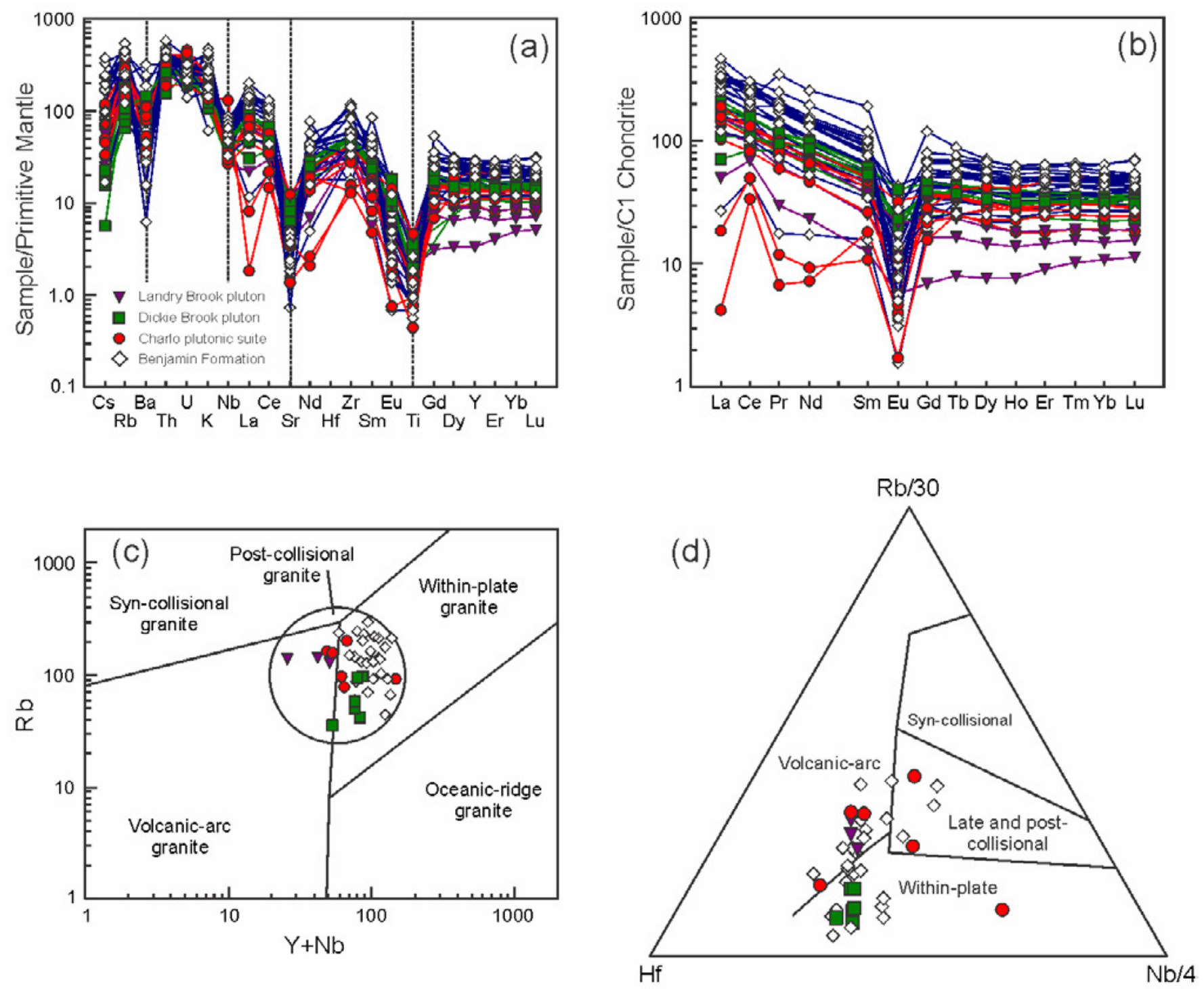

Fig. 12. Comparison of felsic ( $\left.>66 \% \mathrm{SiO}_{2}\right)$ plutonic and volcanic samples. (a) Primitive mantle-normalized trace-element spider diagram with normalizing values from Sun and McDonough (1989). (b) Chondrite-normalized REE diagram with normalizing values from Sun and McDonough (1989). (c) Rb against $\mathrm{Y}+\mathrm{Nb}$ granitoid tectonomagmatic diagram of Pearce et al. (1984) with addition of post-collisional field from Pearce (1996a). (d) Hf-Rb-Nb diagram of Harris et al. (1986). Data for the Benjamin Formation are from R. Wilson (unpublished data). Symbols are shown in Fig. 12a.

the within-plate/post-collisional/volcanic-arc granite fields (Figs. 12c, d), consistent with a co-magmatic relationship. Dostal et al. (1989) suggested a within-plate setting based on their study of the volcanic rocks.

\section{TECTONIC IMPLICATIONS}

The complex history of the Appalachian orogen can be summarized in terms of processes related to the Palaeozoic closure of the Iapetus and Rheic oceans, which led to the accretion of arcs, back arcs, and microcontinents to Laurentia (e.g., van Staal et al. 2009). Temporally, the emplacement of the Landry Brook and Dickie Brook plutons and Charlo plutonic suite was associated with the accretion of Ganderia to Laurentia. However, Ganderia itself has a complex tectonic history both prior to and after accretion to Laurentia (van Staal et al. 2009). Remnants of the Popelogan-Victoria arc and rocks deposited in the associated Tetagouche-Exploits back-arc basin (e.g., van Staal et al. 2003) were accreted to Laurentia (forming the Bathurst Subduction Complex) during the Early Silurian, prior to the arrival of the main part of Ganderia (i.e., during the early phase of the Salinic orogeny; Fig. 13a). This was followed by the Devonian Acadian orogeny, which was associated with the collision of Avalonia and Laurentia (Fig. 13b). 
(a) WENLOCKIAN-PRIDOLIAN; ca. 428-416 Ma (LATE SALINIC OROGENY)

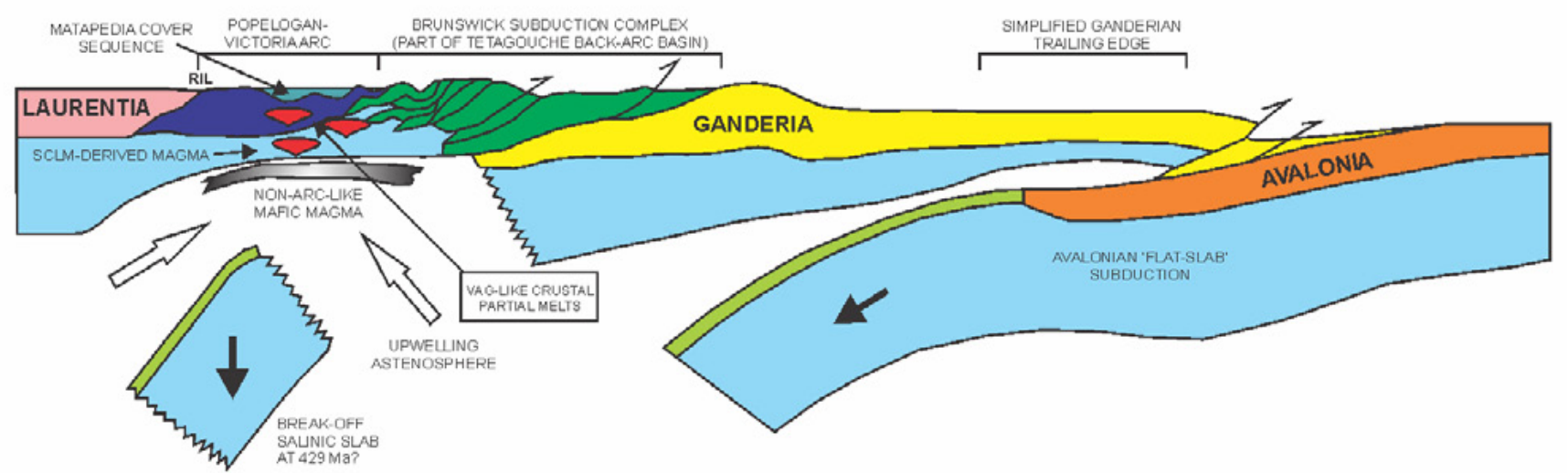

(b) EMSIAN; ca. 407-398 Ma (LATE ACADIAN OROGENY)

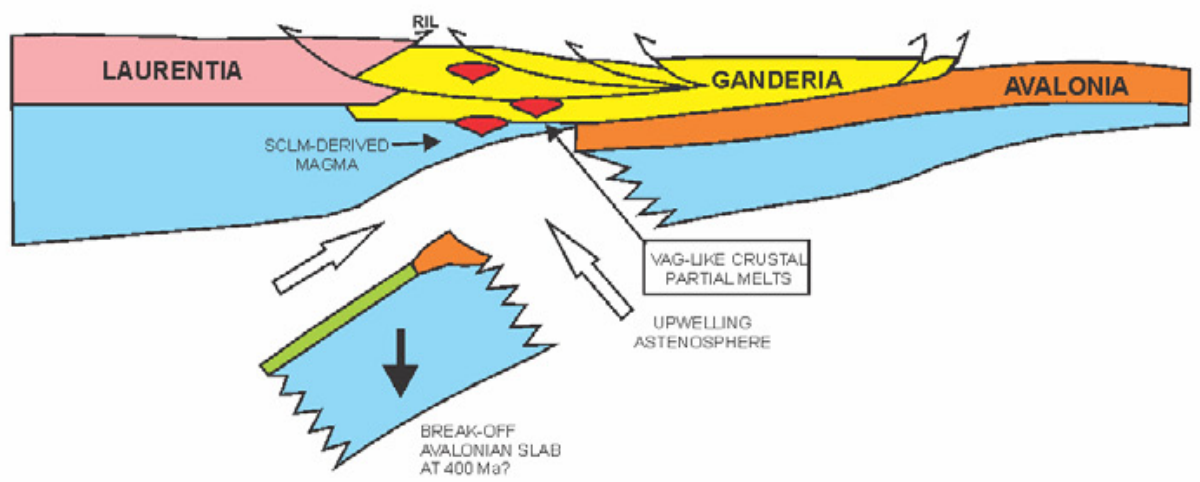

Fig. 13. Tectonic models for the northern Appalachian orogen in the Silurian-Devonian and post-closure slab break-offrelated magmatism within the Popelogan-Victoria arc. (a) Salinic to Late Salinic orogeny showing the already accreted Popelogan-Victoria arc (PVA), amalgamation of the Brunswick Subduction Complex (BMC) and Ganderia. (b) Devonian Acadian orogeny showing the collision of the leading-edge of Avalonia with composite Ganderia (including PVA and BMC). Diagrams are modified after van Staal et al. $(2008,2009)$ and Whalen et al. (2006). Abbreviation: RIL; Red Indian Line, SCLM; sub-continental lithospheric mantle, VAG: volcanic-arc granite.

Based on geological and chemical characteristics of the sedimentary and volcanic rocks in the region, including Québec, Wilson et al. (2008) suggested that subduction of the Tetagouche-Exploits back-arc crust ceased by the Early Wenlockian (ca. $428 \mathrm{Ma}$, coincident with the arrival of the leading edge of Ganderia), and was followed by uplift and extension during the Wenlockian to Pridolian (ca. 428-416 Ma; Fig. 13a). Wilson et al. (2008) suggested that slab-breakoff occurred after the last "gasp" of subduction-related calcalkaline rocks represented by ash tuff dated at ca. $429 \mathrm{Ma}$ (i.e., Pointe Rochette ash; Fig. 14) in the lower part of the Quinn Point Group. Wilson et al. (2008) further suggested that extensional magmatism associated with slab break-off is manifested in the bimodal within-plate volcanic rocks of the Bryant Point and Benjamin formations (Dickie Cove Group). These rocks generally post-dated structures formed during the Salinic orogeny but predated development of
Acadian structures in the area; that is, they were emplaced to the northwest of the migrating Acadian deformation front (Bradley and Tucker 2002). The results of this study have shown that the Landry Brook and Dickie Brook plutons and Charlo plutonic suite are the intrusive equivalents of these volcanic units.

This sequence of events is consistent with those interpreted to have occurred along strike in Newfoundland with slab breakoff and uplift following Salinic collision (Whalen et al. 2006). Based on extensive geochronological, geochemical and isotopic data, Whalen et al. (2006) demonstrated the compositional and spatial variations within the magmatic belt, involving rapid progression from exclusively arc-type to non-arc-like mafic magmatism, with a short episode of "A-type" granite generation, followed by contemporaneous emplacement of granitoids with both within-plate and volcanic-arc characteristics. 
Volcanic/plutonic rocks $\quad \underline{\text { Tectonic events }}$

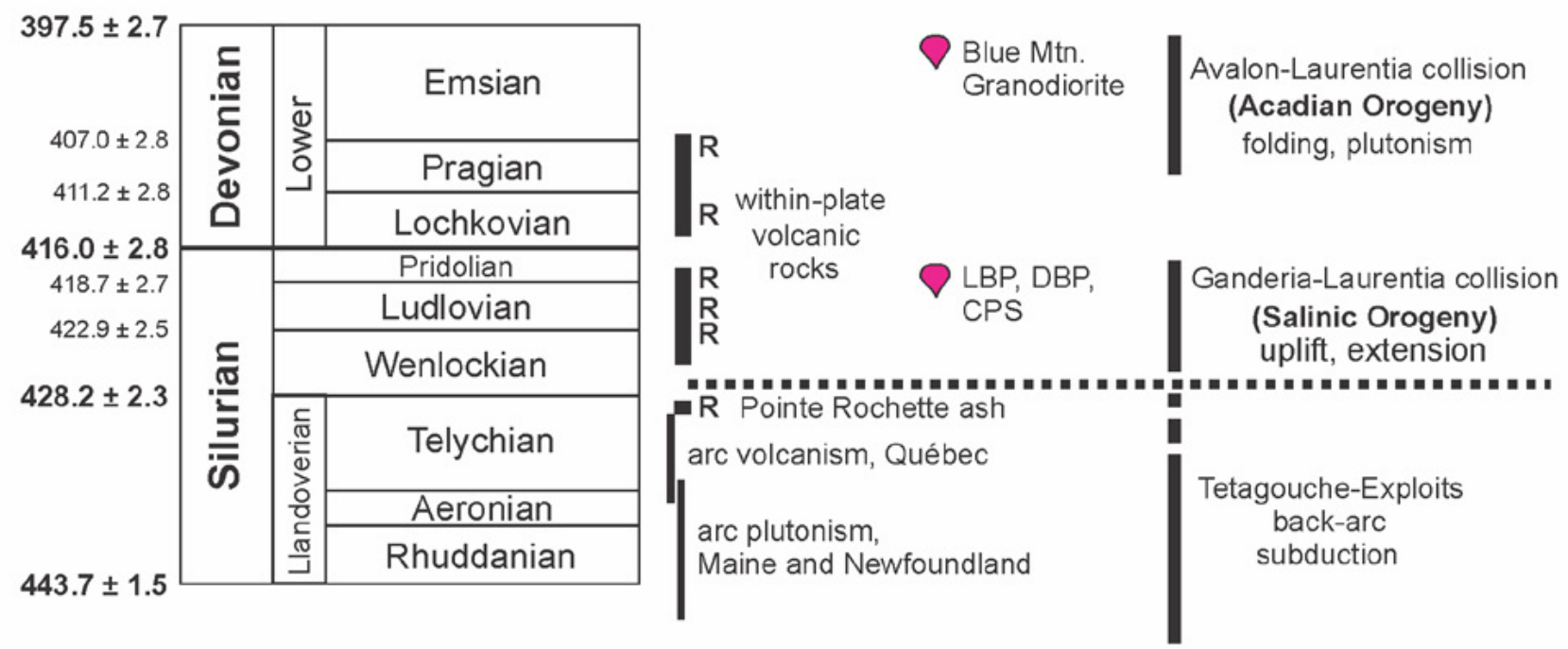

Fig. 14. Summary of volcanic and tectonic events in northern New Brunswick with the addition of the time of emplacement for the Landry Brook (LBP) and Dickie Brook (DBP) plutons and Charlo plutonic suite (CPS) and time of emplacement of the Blue Mountain Granodiorite (modified after Wilson et al. 2008). R: age of volcanic rocks established by U-Pb dating.

Many mantle melts can be influenced by contamination from the crust and hence may display some chemical characteristics of volcanic-arc rocks without being associated temporally with the partial melting of a subducted slab; however, it is most likely that arc-type chemical signatures observed in volcanic and plutonic rocks in the study area arise from contamination of the asthenospheric source by previous subduction events. This likely explains the I-type granitoid characteristics of the three studied plutons.

The Blue Mountain Granodiorite and dacite porphyry of the Charlo plutonic suite are temporally related to the collision of Avalonia with composite Laurentia (Fig. 13b). Widespread magmatism associated with this event is attributed to 'flat-slab' subduction (Murphy et al. 1999), somewhat analogous to the Laramide in the western USA and the present-day Andes in central Chile and Argentina (Kay and Abruzzi 1996; van Staal et al. 2009). Their chemical volcanic-arc affinities are consistent with this model, but it is difficult to envisage why such plutonism would be so sparsely distributed over such a wide area.

\section{CONCLUSIONS}

This work has demonstrated that the Landry Brook and Dickie Brook plutons and the Charlo plutonic suite are approximately contemporaneous and Late Silurian in age. The close petrochemical similarity between quartz monzodiorite/monzogranite unit of the Landry Brook pluton, all units of the Dickie Brook pluton, and the quartz monzodiorite/monzogranite of the Charlo plutonic suite suggest that they share a common, or at least similar, mantle source, and a similar petrogenetic history. The mafic and felsic phases of the plutons show chemical affinities with mafic and felsic volcanic rocks, respectively, of the Benjamin and Bryant Point formations, suggesting that they are cogenetic. The geological and chemical characteristics are consistent with emplacement in a post-collisional extensional regime. The magma was probably generated as a result of slab break-off and resultant high heat flow associated with upwelling asthenosphere under the extinct Popelogan-Victoria arc following closure of the TetagoucheExploits back-arc basin (Salinic collision). Another pulse of magmatic activity occurred ca. $400 \mathrm{Ma}$, as indicated by Blue Mountain Granodiorite (and probably dacite porphyry of the Charlo plutonic suite); however, the causes of the later magmatic pulse (ca. 400-415 Ma) are not addressed in this study, and are probably associated with a somewhat different tectonic setting and different petrogenetic processes.

\section{ACKNOWLEDGEMENTS}

This paper results from a M.Sc. thesis by J-L. Pilote at Acadia University. We thank journal reviewers J. B. Whalen and L.R. Fyffe for their helpful comments and suggestions. Funding and logistical support were provided by the New Brunswick Department of Natural Resources, a Research 
Grant to J-L. Pilote from the Geological Society of America, and Discovery Grant to S.M. Barr from the Natural Sciences and Engineering Research Council of Canada.

\section{REFERENCES}

Bradley, D.C., and Tucker, R. 2002. Emsian synorogenic paleogeography of the Maine Appalachians. Journal of Geology, 110, pp. 483-492. http://dx.doi. org/10.1086/340634

Cabanis, B., and Lecolle, M. 1989. The La/10-Y/15-Nb/8 diagram; a tool for distinguishing volcanic series and discovering crustal mixing and/or contamination. Comptes Rendus de l'Academie des Sciences, Serie 2, Mecanique, Physique, Chimie, Sciences de l'Univers, Sciences de la Terre, 309, pp. 2023-2029.

Cawthorn, R. G., and Brown, P. A., 1976. A model for the formation and crystallization of corundum-normative calc-alkaline magmas through amphibole fractionation. Journal of Geology, 84, pp. 467-476. http://dx.doi. org/10.1086/628212

Deering, C.D., and Bachmann, O. 2010. Trace element indicators of crystal accumulation in silicic igneous rocks. Earth and Planetary Science Letters, 297, Issues 1-2, pp. 324-331.

Dostal, J., Wilson, R.A., and Keppie, J.D. 1989. Geochemistry of Siluro-Devonian Tobique volcanic belt in northern and central New Brunswick (Canada): Tectonic implications. Canadian Journal of Earth Sciences, 26, pp. 1282-1296. http://dx.doi.org/10.1139/e89-108

Fyffe, L.R., Pajari, G.E. Jr., and Cherry, M.E. 1981. The Acadian plutonic rocks of New Brunswick. Maritime Sediments and Atlantic Geology, 17, pp. 23-36.

Gerstenberger, H., and Haase, G., 1997. A highly effective emitter substance for mass spectrometric $\mathrm{Pb}$ isotope ratio determinations. Chemical Geology, 136, pp. 309-312. http://dx.doi.org/10.1016/S0009-2541(96)00033-2

Greiner, H.R. 1970. Geology of the Charlo Area, N.T.S. 21 O/16, Restigouche County. New Brunswick Department of Natural Resources, Mineral Resources Branch, Map Series 70-2, $18 \mathrm{p}$.

Harris, N.B.W., Pearce, J.A., and Tindle, A.G. 1986. Geochemical characteristics of collision-zone magmatism; collision tectonics. Geological Society Special Publication, 19, pp. 67-81.

Hibbard, J.P., van Staal, C.R., Rankin, D.W., and Williams, H. 2006. Lithotectonic map of the Appalachian Orogen, Canada-United States of America. Geological Survey of Canada, Map 2096A, scale 1:1500 000.

Irrinki, R.R. 1990. Geology of the Charlo area; Restigouche County, New Brunswick. Report of Investigations, New Brunswick, Mineral Resources Branch, Report 24, 118 p. Irvine, T.N., and Baragar, W. R. A. 1971. A guide to the chemical classification of the common volcanic rocks. Canadian Journal of Earth Sciences, 8, pp. 523-548. http://dx.doi.org/10.1139/e71-055

Jaffey, A.H., Flynn, K.F., Glendenin, L.E., Bentley, W.C., and Essling, A.M. 1971. Precision measurement of half-lives and specific activities of ${ }^{235} \mathrm{U}$ and ${ }^{238} \mathrm{U}$. Physical Review, 4, pp. 1889-1906.

Kay, S.M., and Abruzzi, J.M. 1996. Magmatic evidence for Neogene lithospheric evolution of the central Andean 'flat-slab' between $30^{\circ} \mathrm{S}$ and $32^{\circ} \mathrm{S}$. Tectonophysics, 259, pp. 15-28. http://dx.doi.org/10.1016/0040-1951(96)00032-7

Kerr, A., Jenner, G.A., and Fryer, B.J. 1995. Sm-Nd isotopic geochemistry of Precambrian to Paleozoic granitoid suites and the deep-crustal structure of the southeast margin of the Newfoundland Appalachians. Canadian Journal of Earth Sciences, 32, pp. 224-245. http://dx.doi. org/10.1139/e95-019

Krogh, T.E., 1973. A low contamination method for hydrothermal decomposition of zircon and extraction of $\mathrm{U}$ and $\mathrm{Pb}$ for isotopic age determinations. Geochimica et Cosmochimica Acta, 37, pp. 485-494. http://dx.doi. org/10.1016/0016-7037(73)90213-5

Krogh, T.E. 1982 Improved accuracy of U-Pb zircon ages by the creation of more concordant systems using an air abrasion technique. Geochimica et Cosmochimica Acta, 46, pp. 637-649. http://dx.doi.org/10.1016/00167037(82)90165-X

Langton, J.P. 2000. Geology of the Balmoral area (NTS 21 O/16e), Restigouche County, New Brunswick. New Brunswick Department of Natural Resources and Energy, Minerals and Energy Division, Plate 2001-28, scale 1:20 000 .

Langton, J.P. 2001. Geology of the South Charlo River area (NTS 21 O/16d), Restigouche County, New Brunswick. New Brunswick Department of Natural Resources and Energy, Minerals and Energy Division, Plate 2001-27, scale 1:20 000 .

Langton, J.P. 2004. Geology of the Blue Mountain area (NTS 21 O/16c), Restigouche County, New Brunswick. New Brunswick Department of Natural Resources, Minerals, Policy and Planning Division, plate 2004-2, scale 1:20 000.

Ludwig, K.R., 2003. User's manual for Isoplot 3.00: A geochronological toolkit for Microsoft Excel. Berkeley Geochronology Center, Special Publication No. 4, 71 p.

Maniar, P.D., and Piccoli, P.M. 1989. Tectonic discrimination of granitoids. Geological Society of America Bulletin, 101, pp. 635-643. http://dx.doi.org/10.1130/00167606(1989) $101<0635:$ TDOG $>2.3 . C O ; 2$

Mattinson, J.M., 2005. Zircon U-Pb chemical abrasion ("CA-TIMS") method: combined annealing and multistep partial dissolution analysis for improved precision and accuracy of zircon ages. Chemical Geology, 220, pp. 47-66. http://dx.doi.org/10.1016/j.chemgeo.2005.03.011

McCutcheon, S.R., and Bevier, M. 1990. Implications of 
field relations and $\mathrm{U}-\mathrm{Pb}$ geochronology for the age of gold mineralization and timing of Acadian deformation in northern New Brunswick. Atlantic Geology, 26, pp. 237-246.

Meschede, M. 1986. A method of discriminating between different types of mid-ocean ridge basalts and continental tholeiites with the Nb-Zr-Y diagram. Chemical Geology, 56, pp. 207-218. http://dx.doi.org/10.1016/00092541(86)90004-5

Murphy, J.B., van Staal, C.R., and Keppie, J.D. 1999. Middle to Late Paleozoic Acadian Orogeny in the northern Appalachians; A Laramide-style plume-modified orogeny? Geology, 27, pp. 653-656. http://dx.doi. org/10.1130/0091-7613(1999)027<0653:MTLPAO>2.3. CO;2

Parrish, R.R., Roddick, J.C., Loveridge, W.D., Sullivan, R.W., and Anonymous, 1987. Uranium-lead analytical techniques at the Geochronology Laboratory, Geological Survey of Canada: Geological Survey of Canada, 87-2, pp. 3-7.

Pearce, J.A. 1996a. Sources and settings of granitic rocks. Episodes, 19, pp. 120-125.

Pearce, J.A. 1996b. A users guide to basalt discrimination diagrams. Geological Association of Canada, Short Course Notes, 12, pp. 79-113.

Pearce, J.A. and Cann, J.R. 1973. Tectonic setting of basic volcanic rocks determined using trace element analyses. Earth and Planetary Science Letters, 19, pp. 290-300. http://dx.doi.org/10.1016/0012-821X(73)90129-5

Pearce, J.A., Harris, N.B., Tindle, and A.G. 1984. Trace element discrimination diagrams for the tectonic interpretation of granitic rocks. Journal of Petrology, 25 (4), pp. 956-983.

Roddick, J.C., Loveridge, W.D., and Parrish, R.R. 1987. Precise $\mathrm{U} / \mathrm{Pb}$ dating of zircon of the sub-nanogram $\mathrm{Pb}$ Level. Chemical Geology: Isotope Geoscience Section, 66, pp. 111-121. http://dx.doi.org/10.1016/01689622(87)90034-0

Ross, P.-S., and Bedard, J.H. 2009. Magmatic affinity of modern and ancient subalkaline volcanic rocks determined from trace-element discriminant diagrams. Canadian Journal of Earth Sciences, 46, pp. 823-839. http://dx.doi.org/10.1139/E09-054

Stacey, J.S., and Kramers, J.D. 1975. Approximation of terrestrial lead isotope evolution by a two stage model. Earth and Planetary Science Letters 26, pp. 207-221. http://dx.doi.org/10.1016/0012-821X(75)90088-6

Stewart, R.D. 1979. The geology of the Benjamin River Intrusive Complex. M.Sc. Thesis, Carleton University, Ottawa, Ontario, $127 \mathrm{p}$.

Sun, S.-S., and McDonough, W.F. 1989. Chemical and isotopic systematics of oceanic basalts: implications for mantle composition and processes. In Magmatism in the ocean basins. Edited by A.D. Saunders and M.J. Norry.
Geological Society, London, pp. 313-345.

Taylor, H. P. 1988. Oxygen, hydrogen and strontium isotope constraints on the origin of granites. Royal Society of Edinburgh Transactions Earth Sciences, 79, pp. 317-338. http://dx.doi.org/10.1017/S0263593300014309

Thirlwall, M.F., Smith, T.E., Graham, A.M., Theodorou, N., Hollings, P., Davidson, J.P., and Arculus R.J. 1994. High field strength element anomalies in arc lavas: source or process? Journal of Petrology, 35, pp. 819-838. http:// dx.doi.org/10.1093/petrology/35.3.819

van Staal, C. R. 2007. Pre-Carboniferous tectonic evolution and metallogeny of the Canadian Appalachians. In Mineral Deposits of Canada: A Synthesis of Major Deposit-types, District Metallogeny, the Evolution of Geological Provinces, and Exploration Methods. Edited by W.D. Goodfellow. Geological Association of Canada, Mineral Deposit Division, Special Publication, 5, pp. 793-818.

van Staal, C.R., Wilson, R.A., Rogers, N., Fyffe, L.R., Langton, J.P., McCutcheon, S.R., McNicoll, V., and Ravenhurst, C.E. 2003. Geology and tectonic history of the Bathurst Supergroup, Bathurst Mining Camp and its relationships to coeval rocks in southwestern New Brunswick and adjacent Maine-a synthesis. In Massive Sulfide Deposits of the Bathurst Mining Camp, New Brunswick and Northern Maine. Edited by W.D. Goodfellow, S.R. McCutcheon, and J.M. Peter. Economic Geology Monograph, 11, pp. 37-60. van Staal, C.R., Currie, K.L., Rowbotham, G., Rogers, N. and Goodfellow, W. 2008. Pressure-temperature paths and exhumation of Late Ordovician-Early Silurian blueschists and associated metamorphic nappes of the Salinic Brunswick subduction complex, northern Appalachians. Geological Society of America Bulletin, 120, pp. 14551477. http://dx.doi.org/10.1130/B26324.1

van Staal, C.R., Whalen, J.B., Valverde-Vaquero, P., Zagorevski, A., and Rogers, R. 2009. Pre-Carboniferous, episodic accretion related, orogenesis along the Laurentian margin of the northern Appalachians. In Ancient orogens and modern analogues. Edited by J.B. Murphy, J.D. Keppie, and A.J. Hynes. Geological Society of London, Special Publication, 327, pp. 271-316.

Walker, J.A., and McCutcheon, S.R. 1995. Siluro-Devonian stratigraphy of the Chaleur Bay Synclinorium, northern New Brunswick. In Current Research 1994. Compiled and Edited by S.A.A. Merlini. New Brunswick Department of Natural Resources and Energy, Minerals and Energy Division, Miscellaneous Report 18, pp. 225-244.

Walker, J.A., Gower, S. and McCutcheon, S.R. 1993. Antinouri-Nicholas Project, Gloucester and Restigouche Counties, northern New Brunswick. In Information Circular, Mineral Resources Branch. Department of Natural Resources. Fredericton, New Brunswick, Report 92-2, pp. 26-29.

Whalen, J.B. 1993. Geology, petrography and geochemistry 
of Appalachian granites in New Brunswick and Gaspésie, Quebec. Geological Survey of Canada, Bulletin 436, 130 p.

Whalen, J.B., Currie, K.L., and Chappell, B.W. 1987. A-type granites; geochemical characteristics, discrimination and petrogenesis. Contributions to Mineralogy and Petrology, 95, pp. 407-419. http://dx.doi.org/10.1007/BF00402202

Whalen, J.B., Jenner, G.A., Hegner, E., Gariepy, C., and Longstaffe, F.J. 1994. Geochemical and isotopic (Nd, O, and $\mathrm{Pb}$ ) constraints on granite sources in the Humber and Dunnage zones, Gaspesie, Quebec, and New Brunswick; Implications for tectonics and crustal structure, Canadian Journal of Earth Sciences, 31, pp. 323-340. http://dx.doi. org/10.1139/e94-030

Whalen, J.B., McNicoll, V.J., van Staal, C.R., Lissenberg, C.J., Longstaffe, F.J., Jenner, G.A., and van Breemen, O. 2006 Spatial, temporal and geochemical characteristics of Silurian collision-zone magmatism, Newfoundland Appalachians: An example of a rapidly evolving magmatic system related to slab break-off. Lithos, 89, pp. 377-404. http://dx.doi.org/10.1016/j.lithos.2005.12.011

Wilson, R.A. 2000. Geology of the Popelogan Lake area (NTS 21 O/15a), Restigouche County, New Brunswick. New Brunswick Department of Natural Resources and Energy, Minerals and Energy Division, Plate 2000-25, scale 1:20 000 .

Wilson, R.A. 2003. Geology of the Campbellton area (NTS 21 O/15), Restigouche County, New Brunswick. New Brunswick Department of Natural Resources; Minerals, Policy and Planning Division, Plate 2003-15, 1:50 000-scale.

Wilson, R.A., and Kamo, S.L. 2008. New U-Pb ages from the Chaleurs and Dalhousie groups: implications for regional correlations and tectonic evolution of northern New Brunswick. In Geological Investigations in New Brunswick for 2007. Edited by G.L. Martin. New Brunswick Department of Natural Resources; Minerals,
Policy and Planning Division, Mineral Resource Report 2008-1, pp. 55-77.

Wilson, R.A., and Kamo, S.L. 2012. The Salinic Orogeny in northern New Brunswick: geochronological constraints and implications for Silurian stratigraphic nomenclature. Canadian Journal of Earth Sciences, 49, pp. 222-238.

Wilson, R.A., Burden, E.T., Bertrand, R., Asselin, E., and McCracken, A.D. 2004. Stratigraphy and tectonosedimentary evolution of the Late Ordovician to Middle Devonian Gaspé Belt in northern New Brunswick: evidence from the Restigouche area. Canadian Journal of Earth Sciences, 41, pp. 527-551. http://dx.doi. org/10.1139/e04-011

Wilson, R.A., van Staal, C.R., and Kamo, S. 2008. Lower Silurian subduction-related volcanic rocks in the Chaleurs Group, northern New Brunswick, Canada. Canadian Journal of Earth Sciences, 45, pp. 981-998. http://dx.doi. org/10.1139/E08-051

Wood, D.A. 1980. The application of a Th-Hf-Ta diagram to problems of tectonomagmatic classification and to establishing the nature of crustal contamination of basaltic lavas of the British tertiary volcanic province. Earth and Planetary Science Letters, 50, pp. 11-30. http:// dx.doi.org/10.1016/0012-821X(80)90116-8

Wood, D.A., Joron, J.L., and Treuil, M. 1979. A re-appraisal of the use of trace elements to classify and discriminate between magma series erupted in different tectonic settings. Earth and Planetary Science Letters, 45, pp. 326336. http://dx.doi.org/10.1016/0012-821X(79)90133-X

York, D. 1969. Least squares fitting of a straight line with correlated errors. Earth and Planetary Science Letters, 5, pp. 320-324. http://dx.doi.org/10.1016/S0012$821 X(68) 80059-7$

Editorial responsibility: David P. West 
Appendix 1. Summary of plutonic units and petrographic features*.

\begin{tabular}{|c|c|c|c|c|c|c|c|c|c|c|}
\hline Plutonic Unit & Grain Size & $\begin{array}{c}\text { Plagioclase } \\
\text { (composition) }\end{array}$ & K-feldspar & Quartz & Clinopyroxene & Amphibole & Biotite & Opaque & Accessory & Other information \\
\hline \multicolumn{11}{|l|}{ Blue Mountain Granodiorite } \\
\hline granodiorite & f.g. $-m . g$. & $\begin{array}{l}\text { sub- to anhedral } \\
\left(\mathrm{An}_{36} \text { to } \mathrm{An}_{40.7}\right)\end{array}$ & $\begin{array}{l}\text { subhedral to } \\
\text { anhedral; } \\
\text { orthoclase }\end{array}$ & interstitial & none & $<3 \%$; nd & $\begin{array}{c}5-10 \% ; \\
\text { phlogopite } \\
\text { to annite }\end{array}$ & $\begin{array}{l}\text { cpy, py, } \\
\text { mag }\end{array}$ & $\begin{array}{l}\text { apatite, } \\
\text { zircon, } \\
\text { titanite }\end{array}$ & $\begin{array}{l}\text { equigranular to } \\
\text { porphyritic, hosts } \mathrm{Cu}- \\
\text { mineralization }\end{array}$ \\
\hline \multicolumn{11}{|l|}{ Landry Brook pluton } \\
\hline gabbro/quartz diorite & f.g.-c.g. & $\begin{array}{l}\text { subhedral, zoned } \\
\left(\mathrm{An}_{44} \text { to } \mathrm{An}_{63}\right)\end{array}$ & none & $\begin{array}{c}\text { trace, } \\
\text { interstitial }\end{array}$ & 20-30\%; diopside & $\begin{array}{l}5 \% \text {; calcic to ferro- } \\
\text { hornblende }\end{array}$ & none & mag, ilm & $\begin{array}{l}\text { apatite, } \\
\text { titanite }\end{array}$ & $\begin{array}{l}\text { Intergranular to ophitic } \\
\text { cpx-plag }\end{array}$ \\
\hline $\begin{array}{l}\text { quartz monzodiorite/ } \\
\text { monzogranite }\end{array}$ & $\mathrm{m} \cdot \mathrm{g}$ & $\begin{array}{l}\text { subhedral, zoned } \\
\left(\mathrm{An}_{30.6} \text { to } \mathrm{An}_{49.3}\right)\end{array}$ & $\begin{array}{l}\text { an- to } \\
\text { subhedral; } \\
\text { orthoclase }\end{array}$ & interstitial & none & $\begin{array}{l}5-15 \% \text {; calcic to } \\
\text { ferro-hornblende }\end{array}$ & $\begin{array}{c}5-7 \% \\
\text { phlogopite } \\
\text { to annite }\end{array}$ & $\begin{array}{c}\text { nd, } \\
\text { secondary? }\end{array}$ & $\begin{array}{l}\text { apatite, } \\
\text { zircon, } \\
\text { titanite }\end{array}$ & Granophyric orthoclase \\
\hline monzogranite & f.g.-m.g & $\begin{array}{l}\text { subhedral, zoned } \\
\left(\mathrm{An}_{18.6} \text { to } \mathrm{An}_{33.3}\right)\end{array}$ & anhedral; nd & interstitial & none & $7 \%$; nd & $\begin{array}{c}7-8 \% ; \\
\text { phlogopite } \\
\text { to annite } \\
\end{array}$ & $\operatorname{mag}$ & $\begin{array}{c}\text { apatite, } \\
\text { zircon }\end{array}$ & $\begin{array}{c}\text { interstial granophyric } \\
\text { texture; perthitic K- } \\
\text { feldspar } \\
\end{array}$ \\
\hline \multicolumn{11}{|l|}{ Dickie Brook pluton } \\
\hline leucogabbro/quartz gabbro & m.g.-c.g. & $\begin{array}{l}\text { subhedral, zoned } \\
\left(\mathrm{An}_{50} \text { to } A n_{60}\right)\end{array}$ & none & $\begin{array}{l}\text { minor, } \\
\text { interstitial }\end{array}$ & $15-25 \%$; augite? & $10 \%$; nd & none & mag, ilm & $\begin{array}{l}\text { apatite, } \\
\text { titanite }\end{array}$ & $\begin{array}{l}\text { Intergranular to ophitic } \\
\text { cpx-plag }\end{array}$ \\
\hline diorite/quartz diorite & m.g.-c.g. & $\begin{array}{l}\text { subhedral, zoned } \\
\left(\mathrm{An}_{25.3} \text { to } \mathrm{An}_{45.3}\right)\end{array}$ & none & interstitial & 10-15\%; diopside & 15-25\%; edenite & none & nd & $\begin{array}{l}\text { apatite, } \\
\text { titanite }\end{array}$ & $\begin{array}{l}\text { abundant inclusions of } \\
\text { apatite in amphibole }\end{array}$ \\
\hline $\begin{array}{l}\text { quartz monzodiorite/ } \\
\text { monzogranite }\end{array}$ & m.g. & $\begin{array}{l}\text { subhedral, zoned } \\
\text { (albite to } \mathrm{An}_{45.3} \text { ) }\end{array}$ & anhedral; nd & interstitial & $\begin{array}{l}5 \% \text {; augite-diopside } \\
\text { and hedenbergite }\end{array}$ & $\begin{array}{c}10-15 \% \text {; ferro- } \\
\text { edenite with low } \mathrm{Mg}\end{array}$ & none & mag, py & $\begin{array}{l}\text { titanite, } \\
\text { minor } \\
\text { apatite }\end{array}$ & perthitic K-feldspar \\
\hline \multicolumn{11}{|l|}{ Charlo plutonic suite } \\
\hline gabbro/diabase & f.g.-m.g. & $\begin{array}{l}\text { lath-shaped } \\
\text { (labradorite) }\end{array}$ & none & $\begin{array}{c}\text { trace, } \\
\text { interstitial }\end{array}$ & $\begin{array}{l}\text { 15-30\%; augite- } \\
\text { diopside }\end{array}$ & none & none & mag & none & $\begin{array}{l}\text { pervasive carbonate } \\
\text { alteration }\end{array}$ \\
\hline quartz monzonite/monzogranite & f.g.-m.g. & $\begin{array}{l}\text { an- to subhedral, } \\
\text { zoned } \\
\left(\mathrm{An}_{17.3} \text { to } \mathrm{An}_{57.3}\right)\end{array}$ & anhedral; nd & interstitial & none & $15 \%$; nd & $\begin{array}{l}15 \% \text {; high } \\
\text { aluminum } \\
\text { phlogopite- } \\
\text { annite }\end{array}$ & nd & $\begin{array}{l}\text { apatite, } \\
\text { zircon, } \\
\text { titanite }\end{array}$ & $\begin{array}{c}\text { granophyric and perthitic } \\
\text { K-feldspar }\end{array}$ \\
\hline quartz rhyolite porphyry & v.f.g.-m.g. & $\begin{array}{c}\text { anhedral } \\
\text { (oligoclase) }\end{array}$ & anhedral; nd & interstitial & none & none & none & none & nd & $\begin{array}{l}\text { highly altered, hiatal } \\
\text { porphyritic }\end{array}$ \\
\hline $\begin{array}{c}\text { hornblende-plagioclase dacite } \\
\text { porphyry }\end{array}$ & v.f.g.-f.g. & $\begin{array}{l}\text { an- to subhedral, } \\
\text { zoned, (nd) }\end{array}$ & anhedral; nd & interstitial & none & $5 \%$; hornblende & secondary & minor & nd & $\begin{array}{l}\text { skeletal hornblende, hiatal } \\
\text { plagioclase-phyric }\end{array}$ \\
\hline
\end{tabular}

*Abbreviations: v.f., f, m, and c.g., very fine-, fine-, medium-, and coarse-grained; cpy, chalcopyrite; cpx, clinopyroxene; ilm, ilmenite; mag, magnetite; plag, plagioclase; py, pyrite; nd, not determined. 
Appendix 2. Chemical data for samples from the Blue Mountain Granodiorite, Landry Brook and Dickie Brook plutons, and Charlo plutonic suite.

\begin{tabular}{|c|c|c|c|c|c|c|c|c|c|c|c|c|c|c|c|c|c|c|c|c|c|c|c|c|c|c|c|}
\hline Sample & Lithology & $\mathrm{SiO}_{2}$ & $\mathrm{Al}_{2} \mathrm{O}_{3}$ & $\mathrm{Fe}_{2} \mathrm{O}_{3}$ & $\mathrm{CaO}$ & $\mathrm{MgO}$ & $\mathrm{Na}_{2} \mathrm{O}$ & $\mathrm{K}_{2} \mathrm{O}$ & $\mathrm{MnO}$ & $\mathrm{TiO}_{2}$ & $\mathrm{P}_{2} \mathrm{O}_{5}$ & LOI & Total & $\mathrm{Rb}$ & $\mathrm{Sr}$ & $\mathrm{Ba}$ & $\mathrm{Zr}$ & $\mathrm{Nb}$ & Y & V & $\mathrm{Ni}$ & $\mathrm{Cu}$ & Co & $\mathrm{Pb}$ & $\mathrm{Zn}$ & Th & U \\
\hline \multicolumn{28}{|c|}{ Blue Mountain Granodiorite } \\
\hline JL-09-024 & granodiorite & 66.40 & 17.02 & 2.95 & 2.82 & 1.44 & 4.97 & 1.76 & 0.07 & 0.43 & 0.15 & 1.62 & 99.63 & 39 & 707 & 413 & 136 & 7 & 7 & 32 & 10 & 17 & 39 & 2 & 90 & 5 & 1 \\
\hline JL-09-057 & granodiorite & 70.40 & 15.33 & 1.88 & 2.14 & 0.83 & 4.50 & 2.70 & 0.02 & 0.30 & 0.07 & 1.40 & 99.57 & 47 & 388 & 443 & 118 & 7 & 8 & 22 & 4 & 108 & 53 & 2 & 13 & 7 & 2 \\
\hline JL-10-139 & granodiorite & 66.00 & 16.78 & 2.98 & 2.95 & 1.84 & 4.71 & 1.42 & 0.05 & 0.44 & 0.09 & 1.84 & 99.16 & 36 & 523 & 365 & 122 & 5 & 7 & 38 & 6 & 394 & 46 & 1 & 32 & 4 & 1 \\
\hline 7020-101 & tonalite & 67.90 & 16.35 & 2.14 & 3.37 & 1.18 & 4.53 & 2.09 & 0.03 & 0.40 & 0.08 & 0.91 & 99.03 & 40 & 581 & 526 & 126 & 5 & 7 & 28 & 8 & 506 & 57 & 1 & 20 & 5 & 1 \\
\hline 7012-130 & granodiorite & 67.30 & 15.97 & 2.68 & 2.76 & 1.07 & 5.11 & 1.93 & 0.07 & 0.37 & 0.10 & 2.35 & 99.78 & 34 & 614 & 442 & 148 & 5 & 6 & 24 & 7 & 30 & 40 & 3 & 63 & 4 & 1 \\
\hline 7003-295 & granodiorite & 66.40 & 15.53 & 2.48 & 3.45 & 1.12 & 3.72 & 2.31 & 0.05 & 0.37 & 0.10 & 4.59 & 100.22 & 53 & 271 & 485 & 146 & 5 & 6 & 25 & 7 & 9 & 23 & 1 & 27 & 4 & 1 \\
\hline \multicolumn{28}{|c|}{ Landry Brook pluton } \\
\hline JL-09-020 & monzogranite & 71.30 & 14.52 & 2.57 & 0.15 & 0.21 & 4.91 & 4.58 & 0.03 & 0.30 & 0.04 & 1.21 & 99.86 & 139 & 68 & 540 & 293 & 15 & 11 & 8 & 1 & 3 & 54 & 3 & 21 & 16 & 3 \\
\hline JL-09-030 & monzogranite & 70.10 & 14.66 & 2.61 & 0.79 & 0.24 & 5.07 & 4.43 & 0.04 & 0.30 & 0.04 & 0.96 & 99.27 & 142 & 121 & 526 & 314 & 18 & 24 & 8 & 1 & 9 & 60 & 18 & 34 & 19 & 4 \\
\hline JL-09-037 & quartz monzonite & 64.50 & 15.49 & 4.82 & 2.11 & 1.19 & 4.35 & 3.71 & 0.07 & 0.77 & 0.19 & 2.19 & 99.43 & 111 & 230 & 488 & 346 & 21 & 33 & 55 & 3 & 3 & 44 & 6 & 34 & 17 & 5 \\
\hline JL-09-072 & quartz monzonite & 64.80 & 15.57 & 4.95 & 2.91 & 1.21 & 4.60 & 3.57 & 0.07 & 0.75 & 0.20 & 0.89 & 99.63 & 135 & 224 & 461 & 398 & 23 & 36 & 53 & 2 & 2 & 58 & 7 & 23 & 19 & 4 \\
\hline JL-10-077 & rhyolite/syenogranite porphyry & 66.10 & 15.39 & 4.36 & 2.57 & 1.15 & 4.45 & 3.77 & 0.08 & 0.66 & 0.18 & 1.34 & 100.15 & 127 & 204 & 460 & 336 & 20 & 30 & 44 & 4 & 10 & 60 & 15 & 42 & 18 & 6 \\
\hline JL-10-081 & monzogranite & 64.40 & 15.43 & 4.57 & 1.93 & 1.12 & 4.28 & 4.24 & 0.11 & 0.74 & 0.18 & 2.39 & 99.41 & 134 & 236 & 495 & 319 & 19 & 33 & 58 & 3 & 2 & 59 & 16 & 78 & 16 & 4 \\
\hline JL-09-086 & gabbro & 47.00 & 18.80 & 7.04 & 12.46 & 9.27 & 1.72 & 0.54 & 0.12 & 0.69 & 0.04 & 2.52 & 100.26 & 18 & 463 & 88 & 31 & 3 & 8 & 109 & 50 & 11 & 53 & 1 & 19 & 1 & 0 \\
\hline \multicolumn{28}{|c|}{ Dickie Brook pluton } \\
\hline JL-09-202 & monzogranite & 67.50 & 14.69 & 5.63 & 1.23 & 0.21 & 6.18 & 2.66 & 0.12 & 0.44 & 0.06 & 0.84 & 99.62 & 42 & 124 & 583 & 453 & 27 & 55 & 8 & 0 & 4 & 57 & 6 & 56 & 10 & 5 \\
\hline JL-09-207 & quartz gabbro & 59.50 & 18.27 & 5.23 & 5.14 & 1.45 & 7.57 & 0.59 & 0.09 & 0.99 & 0.30 & 0.85 & 100.01 & 6 & 461 & 400 & 579 & 11 & 42 & 58 & 1 & 3 & 59 & 2 & 14 & 6 & 1 \\
\hline JL-09-209 & monzogranite & 66.00 & 15.42 & 5.68 & 1.26 & 0.48 & 7.30 & 1.58 & 0.16 & 0.49 & 0.09 & 1.29 & 99.86 & 25 & 159 & 634 & 657 & 28 & 49 & 8 & 0 & 4 & 50 & 4 & 61 & 10 & 3 \\
\hline JL-09-214-1 & monzogranite & 70.90 & 14.40 & 2.22 & 1.25 & 0.38 & 5.76 & 3.62 & 0.03 & 0.30 & 0.04 & 0.69 & 99.67 & 51 & 179 & 709 & 462 & 25 & 51 & 8 & 1 & 1 & 73 & 4 & 11 & 19 & 4 \\
\hline JL-09-220 & monzogranite/granodiorite & 70.80 & 14.05 & 2.93 & 0.52 & 0.23 & 5.56 & 3.78 & 0.05 & 0.30 & 0.03 & 0.86 & 99.19 & 94 & 116 & 497 & 413 & 27 & 52 & 8 & 0 & 2 & 72 & 7 & 28 & 17 & 5 \\
\hline JL-09-228 & diorite/gabbro & 53.80 & 21.94 & 4.25 & 7.30 & 1.73 & 6.17 & 0.83 & 0.13 & 1.03 & 0.28 & 2.00 & 99.49 & 18 & 700 & 391 & 614 & 10 & 25 & 167 & 11 & 18 & 44 & 45 & 98 & 5 & 1 \\
\hline JL-09-229 & hornblende quartz diorite & 50.80 & 20.21 & 7.99 & 9.66 & 2.78 & 4.42 & 0.56 & 0.11 & 2.16 & 0.09 & 0.69 & 99.52 & 9 & 593 & 214 & 125 & 9 & 16 & 311 & 4 & 27 & 55 & 5 & 23 & 2 & 1 \\
\hline JL-09-235 & quartz monzodiorite & 55.70 & 16.96 & 9.02 & 5.35 & 2.28 & 5.41 & 1.65 & 0.14 & 1.60 & 0.45 & 1.14 & 99.77 & 38 & 428 & 430 & 231 & 26 & 51 & 93 & 1 & 6 & 55 & 3 & 16 & 7 & 2 \\
\hline JL-10-304 & quartz gabbro & 52.40 & 15.70 & 11.16 & 8.43 & 3.61 & 4.27 & 0.40 & 0.18 & 2.40 & 0.34 & 0.90 & 99.86 & 7 & 380 & 214 & 289 & 23 & 40 & 310 & 6 & 43 & 51 & 2 & 18 & 5 & 1 \\
\hline JL-10-311 & quartz monzodiorite & 64.10 & 16.52 & 2.50 & 3.31 & 2.36 & 7.00 & 0.75 & 0.04 & 0.69 & 0.08 & 1.65 & 99.00 & 18 & 368 & 129 & 197 & 9 & 21 & 83 & 2 & 0 & 33 & 1 & 5 & 10 & 3 \\
\hline JL-10-322 & tonalite & 63.60 & 16.11 & 5.46 & 2.00 & 0.93 & 6.44 & 2.49 & 0.07 & 0.68 & 0.23 & 1.81 & 99.90 & 60 & 296 & 473 & 561 & 28 & 41 & 24 & 2 & 7 & 44 & 2 & 31 & 14 & 5 \\
\hline JL-10-373 & granodiorite & 57.00 & 14.71 & 8.27 & 6.19 & 2.87 & 5.29 & 1.24 & 0.15 & 2.06 & 0.44 & 0.84 & 99.08 & 24 & 329 & 298 & 371 & 22 & 53 & 192 & 3 & 10 & 48 & 6 & 38 & 8 & 3 \\
\hline JL-10-383 & quartz monzodiorite & 59.60 & 16.49 & 3.46 & 6.68 & 2.00 & 7.89 & 0.35 & 0.08 & 1.51 & 0.55 & 1.15 & 99.78 & 7 & 478 & 141 & 553 & 33 & 73 & 54 & 1 & 1 & 49 & 2 & 10 & 10 & 5 \\
\hline JL-10-386 & monzogranite & 71.50 & 14.15 & 2.39 & 0.69 & 0.13 & 5.38 & 3.72 & 0.03 & 0.31 & 0.03 & 0.87 & 99.28 & 59 & 143 & 733 & 399 & 25 & 51 & 8 & 2 & 1 & 70 & 4 & 17 & 16 & 4 \\
\hline \multicolumn{28}{|c|}{ Charlo Plutonic suite } \\
\hline JL-10-006 & quartz monzonite & 57.90 & 14.37 & 8.87 & 2.56 & 2.40 & 4.68 & 3.18 & 0.17 & 1.47 & 0.41 & 2.55 & 98.68 & 104 & 437 & 567 & 286 & 25 & 49 & 122 & 2 & 8 & 33 & 4 & 97 & 10 & 3 \\
\hline JL-10-007 & quartz monzodiorite & 62.60 & 15.19 & 6.53 & 2.33 & 1.35 & 4.86 & 3.57 & 0.14 & 1.04 & 0.28 & 1.67 & 99.60 & 111 & 217 & 643 & 467 & 26 & 50 & 60 & 3 & 9 & 55 & 13 & 77 & 12 & 3 \\
\hline JL-10-019 & microgranite & 65.30 & 14.38 & 6.12 & 1.21 & 1.11 & 3.32 & 4.10 & 0.08 & 0.92 & 0.23 & 2.94 & 99.75 & 136 & 85 & 413 & 496 & 26 & 47 & 51 & 4 & 9 & 35 & 8 & 61 & 15 & 4 \\
\hline JL-10-039 & dacite porphyry & 67.50 & 15.58 & 2.32 & 2.78 & 1.01 & 5.55 & 1.39 & 0.03 & 0.42 & 0.09 & 2.96 & 99.69 & 26 & 601 & 263 & 121 & 4 & 7 & 38 & 4 & 2 & 41 & 4 & 23 & 4 & 1 \\
\hline JL-10-058 & rhyolite/syenogranite & 73.70 & 13.52 & 1.84 & 0.38 & 0.16 & 4.16 & 4.68 & 0.02 & 0.23 & 0.03 & 1.06 & 99.83 & 162 & 62 & 406 & 231 & 17 & 31 & 8 & 1 & 2 & 95 & 12 & 26 & 23 & 6 \\
\hline$J L-10-060$ & rhyolite porphyry & 77.20 & 13.33 & 0.70 & 0.02 & 0.13 & 4.24 & 3.04 & 0.01 & 0.07 & 0.01 & 1.27 & 100.06 & 91 & 68 & 163 & 130 & 73 & 73 & 8 & 1 & 1 & 45 & 5 & 51 & 15 & 7 \\
\hline JL-10-092 & rhyolite porphyry & 73.70 & 13.36 & 2.12 & 0.18 & 0.11 & 3.34 & 5.04 & 0.05 & 0.20 & 0.01 & 1.51 & 99.65 & 157 & 62 & 441 & 228 & 15 & 38 & 8 & 1 & 2 & 48 & 3 & 29 & 21 & 8 \\
\hline JL-10-093 & rhyolite porphyry & 76.70 & 12.16 & 1.20 & 0.25 & 0.12 & 4.56 & 3.54 & 0.02 & 0.12 & 0.01 & 0.79 & 99.47 & 96 & 61 & 266 & 110 & 20 & 42 & 8 & 0 & 2 & 58 & 38 & 170 & 26 & 7 \\
\hline JL-10-094 & alkali rhyolite porphyry & 77.00 & 11.83 & 1.11 & 0.01 & 0.05 & 2.86 & 5.19 & 0.01 & 0.15 & 0.02 & 1.18 & 99.42 & 205 & 25 & 193 & 108 & 21 & 45 & 8 & 0 & 0 & 65 & 1 & 15 & 20 & 8 \\
\hline JL-10-104 & diabase & 46.30 & 16.91 & 11.83 & 2.21 & 6.58 & 4.38 & 1.58 & 0.16 & 2.07 & 0.28 & 6.34 & 98.73 & 44 & 1747 & 941 & 176 & 13 & 26 & 275 & 52 & 34 & 51 & 2 & 77 & 2 & 1 \\
\hline JL-10-108 & diabase & 47.40 & 16.47 & 11.96 & 5.45 & 6.07 & 4.75 & 0.68 & 0.18 & 2.45 & 0.41 & 4.03 & 99.93 & 15 & 915 & 913 & 276 & 15 & 32 & 172 & 34 & 28 & 48 & 2 & 72 & 2 & 1 \\
\hline JL-10-113 & monzogranite & 66.50 & 14.94 & 5.18 & 1.29 & 0.81 & 5.19 & 2.87 & 0.10 & 0.73 & 0.21 & 1.84 & 99.74 & 77 & 220 & 566 & 350 & 16 & 47 & 32 & 1 & 9 & 42 & 8 & 61 & 12 & 3 \\
\hline JL-10-119 & gabbro/quartz gabbro & 50.60 & 16.68 & 9.54 & 4.91 & 5.54 & 4.19 & 1.26 & 0.19 & 1.70 & 0.30 & 4.78 & 99.76 & 30 & 690 & 1027 & 247 & 23 & 27 & 144 & 20 & 22 & 37 & 5 & 61 & 5 & 2 \\
\hline
\end{tabular}

Notes: Analyses were done by X-ray Fluorescence for major oxides and ICP-MS for trace elements at the ACME Laboratory in Vancouver, British Columbia, Canada. Analytical error is generally less than $5 \%$ for major element and 2-10\% for trace elements. $\mathrm{Fe}_{2} \mathrm{O}_{3}$ is total $\mathrm{Fe}$ as $\mathrm{Fe}_{2} \mathrm{O}_{3}$. LOI is loss on ignition at $1000^{\circ} \mathrm{C}$ 
Appendix 3. Rare-earth element, Hf, and Ta data* from the Blue Mountain Granodiorite, Landry Brook and Dickie Brook plutons, and Charlo plutonic suite.

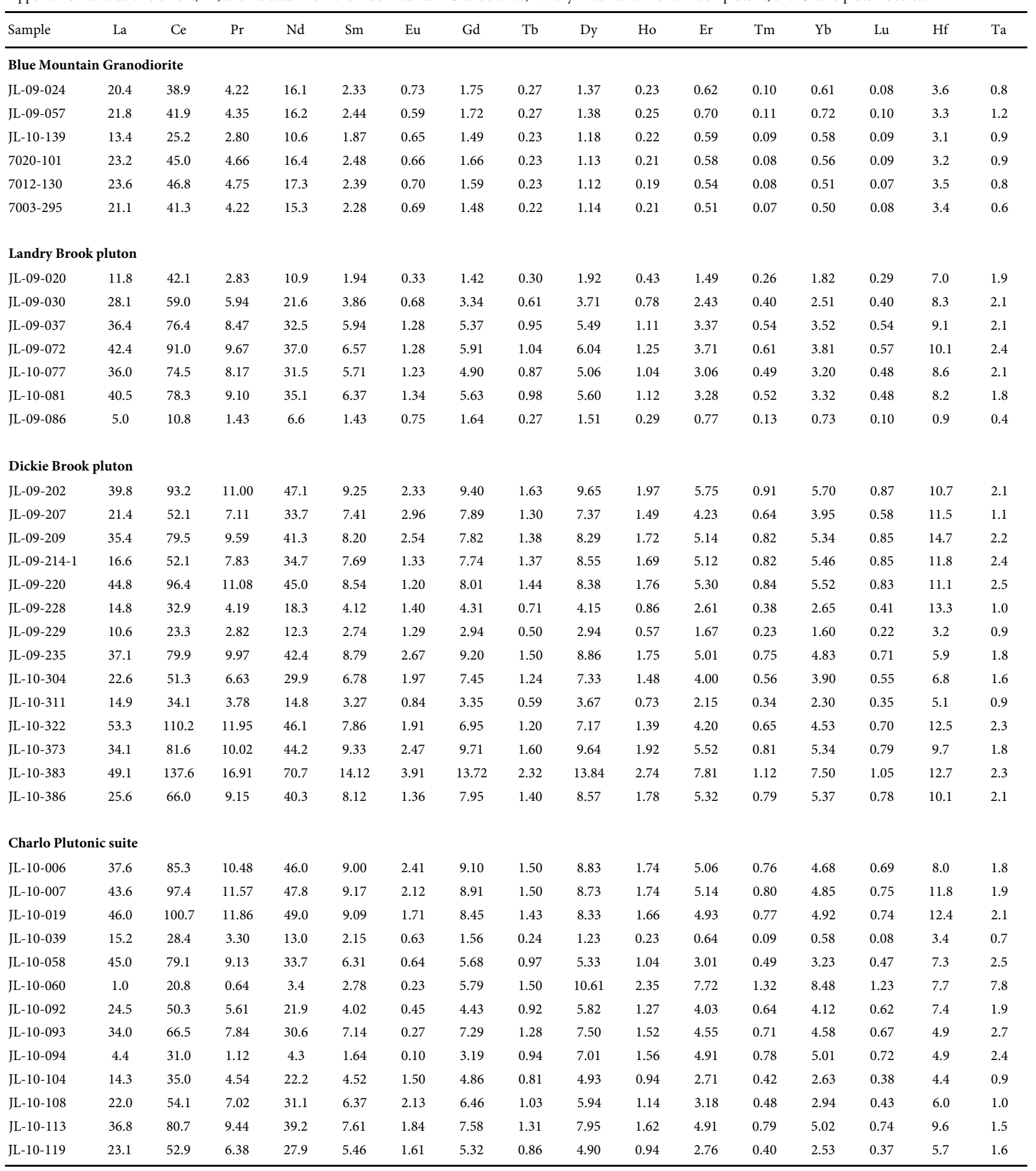

*Analyses at ACME Laboratory in Vancouver, British Columbia, Canada, using ICP-MS. 